\title{
2-Piece Cork Stoppers as Alternative for Valorization of Thin Cork Planks: Analysis by LCA Methodology
}

\author{
Francisco Javier Flor-Montalvo ${ }^{1, *}$, Agustín Sánchez-Toledo Ledesma ${ }^{1} \oplus$, Eduardo Martínez Cámara ${ }^{2}$, \\ Emilio Jiménez-Macías ${ }^{3}{ }^{(0)}$, Jorge Luis García-Alcaraz ${ }^{4}(\mathbb{C})$ and Julio Blanco-Fernandez ${ }^{2}$ (i) \\ 1 Higher School of Engineering and Technology, International University of La Rioja (UNIR), \\ 26004 Logroño, La Rioja, Spain; agustin.sancheztoledo@unir.net \\ 2 Department of Mechanical Engineering, University of La Rioja, Luis de Ulloa 20, \\ 26004 Logroño, La Rioja, Spain; eduardo.martinezc@unirioja.es (E.M.C.); julio.blanco@unirioja.es (J.B.-F.) \\ 3 Department of Electrical Engineering, University of La Rioja, Luis de Ulloa 20, 26004 Logroño, La Rioja, Spain; \\ Emilio.jimenez@unirioja.es \\ 4 Department of Industrial Engineering and Manufacturing, Autonomous University of Ciudad Juarez, \\ Ciudad Juárez CHIH 32315, Mexico; jorge.garcia@uacj.mx \\ * Correspondence: franciscojavier.flor@unir.net; Tel.: +34-640-522-344
}

check for updates

Citation: Flor-Montalvo, F.J.; Ledesma, A.S.-T.; Cámara, E.M.; Jiménez-Macías, E.; García-Alcaraz, J.L.; Blanco-Fernandez, J. 2-Piece Cork Stoppers as Alternative for Valorization of Thin Cork Planks: Analysis by LCA Methodology. Foods 2021, 10, 873. https://doi.org/ $10.3390 /$ foods 10040873

Academic Editors:

Susana Guzmán-Puyol, José

Jesús Benítez and José

Alejandro Heredia-Guerrero

Received: 10 February 2021

Accepted: 13 April 2021

Published: 16 April 2021

Publisher's Note: MDPI stays neutral with regard to jurisdictional claims in published maps and institutional affiliations.

Copyright: (c) 2021 by the authors. Licensee MDPI, Basel, Switzerland. This article is an open access article distributed under the terms and conditions of the Creative Commons Attribution (CC BY) license (https:/ / creativecommons.org/licenses/by/ $4.0 /)$.

\begin{abstract}
Natural stoppers are a magnificent closure for the production of aging wines and unique wines, whose application is limited by the availability of raw materials and more specifically of cork sheets of different thickness and quality. The growing demand for quality wine bottle closures leads to the search for alternative stopper production. The two-piece stopper is an alternative since it uses non-usable plates in a conventional way for the production of quality caps. The present study has analyzed the impact of the manufacture of these two-piece stoppers using different methodologies and for different dimensions by developing an LCA (Life Cycle Assessment), concluding that the process phases of the plate, its boiling, and its stabilization, are the phases with the greatest impact. Likewise, it is detected that the impacts in all phases are relatively similar (for one $\mathrm{kg}$ of net cork produced), although the volumetric difference between these stoppers represents a significant difference in impacts for each unit produced.
\end{abstract}

Keywords: life cycle assessment; cork stoppers; thin cork planks; valorization

\section{Introduction}

\subsection{The Cork Oak}

The cork oak is a tree that belongs to the Quercus genus; hence, its name Quercus suber L. It is a tree with green leaves throughout the year that, for an adult specimen, has an average height of between 10 and $15 \mathrm{~m}$ and a diameter between 0.3 and $1 \mathrm{~m}[1,2]$

The cork oak is a species associated with the Mediterranean Sea. The climate is dry in summer, with high temperatures and little rainfall, while winters have mild temperatures and abundant rainfall, although they tend to be irregular, alternating periods of great abundance of water with others of drought [3].

Within the Mediterranean climate zones, the cork oak is more common in those areas with a great oceanic influence that favors a damping of both the effects of drought and temperature. This fact, combined with the great light needs of the cork oak, determine the presence of this arboreal species in very specific areas. Likewise, it is a species that does not proliferate outside the areas and conditions outlined, which makes cork a unique, scarce and valuable product [4]. In these forests it can be found both as a min tree species and together with other Mediterranean trees [5].

The bark of the cork oak is very thick, grayish in color, and usually cracked. During the "saca" or extraction of the cork, the trunk without the bark presents a reddish-yellowish color [6,7]. The main use of the cork oak is the product known as cork. Cork is the bark 
of the cork oak and has peculiar characteristics, among which are its lightness, flexibility, high coefficient of friction, impermeability, which, provided that it is natural, recyclable, and renewable, makes it a very interesting material for various applications $[7,8]$.

\subsection{The Cork Manufacture}

Modern cork manufacture dates back to the mid-18th century. Initially, and until the end of the 19th century, it was a business destined to the wine sector and more specifically to the manufacture of cork stoppers for still and sparkling wines.

The stoppers manufactured were in any case natural stoppers made from cork sheet. At the beginning of the 20th century, and faced with the impossibility of meeting the demands for stoppers for closing wines and sparkling wines, new products appeared, among which the agglomerated cork stopper stands out. The main advantage of these stoppers was the possibility of manufacturing them from cork sheets that, due to their thickness and geometry, could not be used to obtain natural stoppers, which allowed increasing the number of stoppers available on the market.

The effect of the appearance of the agglomerate had two immediate consequences in the productive manufacturing structures. In the first place, the great cork transforming powers during the 19th century, Spain and to a lesser extent Portugal, reduced their weight with the entry of new competitors. This led to a reindustrialization of the cork sector in Spain and to a lesser extent in Portugal $[9,10]$. On the other hand, the demand for cork for non-oenological uses, although it primarily used thin cork (also known as branch cork), it also diverted part of the cork traditionally used for the manufacture of natural stoppers, reducing the availability of this type of stoppers [11]. Currently, Spain and Portugal account for more than $80 \%$ of the cork extracted (Portugal exports $62.4 \%$ of all the cork in the world, followed by Spain with $18.5 \%$ according to 2017 data) and more than $60 \%$ of the world's cork oak area available.

Although in the last 4 years the vineyard area in the world has experienced a decrease, the wine area in 2018 stabilized at around 7.4 million hectares and the volume of exports from all countries reached a volume of $108.0 \mathrm{M} \mathrm{hL}$ and a value of EUR $31300 \mathrm{M}$. Of these, bottled wines accounted for $53 \%$ of the total international wine trade by volume, although these bottled wines represent $70 \%$ of all exported wines in terms of total economic value [11].

Based on the foregoing, it can be deduced how the market is being segmented into wines of increasing quality and usually associated with careful and/or unique aging, while the weight of lower added value wines, usually associated with the bulk sales, decreases.

\subsection{The Natural Stopper and the Two-Piece Natural Stopper}

Based on the data presented, it is evident that, although the natural stopper is a magnificent closure for the production of aging wines and singular wines, only those stoppers of high quality and usually associated with wines of medium and high categories are accepted by the current market.

There are serious limitations regarding the total annual cork production and its recurrence that, together with the development of new substitute products for both cork (agglomerate, technical stopper, microgranulates, etc.) and other materials (polymeric closures, screw cap, etc.) has made many products migrate to this type of closures.

In any case, and in the face of a growing market for quality and bottled wines, the demand for high-end stoppers is greater, although the supply cannot be increased.

Nor would an adequate forestry policy allow a substantial increase in the amount of cork available in the medium term due to the long maturation period of the cork oak forest before producing its first extraction of cork useful for the wine sector.

Under these circumstances, the opportunity arises to manufacture two-piece stoppers from cork sheets that are less thick and which cannot be used to make one-piece stoppers.

A two-piece stopper is a stopper made up of two semi-cylindrical halves glued together in the middle. 
It maintains the main characteristics of the natural one-piece stopper, at a slightly lower cost and with some additional advantages:

- Greater use of raw materials in the production of high added value caps.

- Less expensive raw materials and the absence of supply problems when competing for their acquisition with other products with lower added value.

- Greater availability of raw materials in the market by competing only with low valueadded processes (cork rolling and cork crushing to agglomerate/microgranulate).

- Branch cork, since it is far from the traditional sources of cork contamination (it is far from humidity, the main cause of the appearance of 2,4,6-Trichloroanisole-TCAmain cause of olfactory defects in wine associated with the use of cork stoppers), which implies lower levels of contamination than conventional cork [12].

- Density and mechanical capacities of the stoppers manufactured with this process, is much higher than those manufactured by conventional processes ("thin" cork has the same number of cell walls for years of growth, but since its thickness is much smaller, the number of cell walls per linear $\mathrm{cm}$ is much higher).

- When working with base plates of less thickness (22\% of the thickness required for the perforation of a conventional stopper), it is much easier to treat said plates in depth using heat treatments and minimize the appearance of TCA.

However, since the manufacturing process is different from that used to produce 1-piece stoppers, the manufacturing impact of this type of two-piece stoppers will also be substantially different.

\subsection{Research Context}

There exist Life Cycle Assessments associated with the stopper manufacturing phases [13-15], which carry out an exhaustive analysis in order to assess the environmental impacts derived from the production of natural cork stoppers in Portugal, in addition to identifying the stages and processes to suggest improvement actions and alternative scenarios, as well as LCA environmental impact analysis for the production of natural cork stoppers $[13,16]$, granules [17], or for champagne bottles [18]. However, the impact of this (two-piece) type of manufacturing process has not been analyzed, which, as it has been indicated, would allow the market to supply high quality stoppers with excellent properties without the limitations associated with the current availability of cork.

In order to complement the information available regarding the Life Cycle Analysis of two-piece cork stoppers, an environmental study is carried out for the manufacture of two-piece natural cork stoppers in the most common dimensions demanded by the market and independently analyzing the different production methods that exist today: drilling and turning.

All the processes will be analyzed from the reception of the raw cork sheet to the achievement of the finished and personalized cork stoppers, ready to be used in the winery to close the wines.

To obtain the primary data, 10 batches of stoppers were measured on the manufacturing process for each type of cap, analyzing diameter, and length.

In the case of caps of the same diameter, the analysis of the initial phases up to the initial cutting of the plate has been carried out jointly.

\subsection{Justification and Object of the Research}

Based on the above, it is evident that there is a growing demand for cork stoppers for aging wines at the same time that the production of quality natural stoppers does not grow in quantity and even decreases with the use of large volumes of cork for manufacturing microgranulated or agglomerated stoppers.

The increase in the availability of raw cork results, as explained above, in a very long process that involves silvicolous work for several decades. 
On the other hand, a thick cork sheet is necessary to be able to produce cork stoppers, those with insufficient thickness being used for the production of agglomerated or microgranulated stoppers, for the production of washers or for other productive sectors.

Based on the foregoing, the two-piece stopper is an acceptable alternative given that it makes it possible to take advantage of the cork with less thickness and produce stoppers that are very similar to the one-piece stopper maintaining a large part of its added value. (Figure 1).

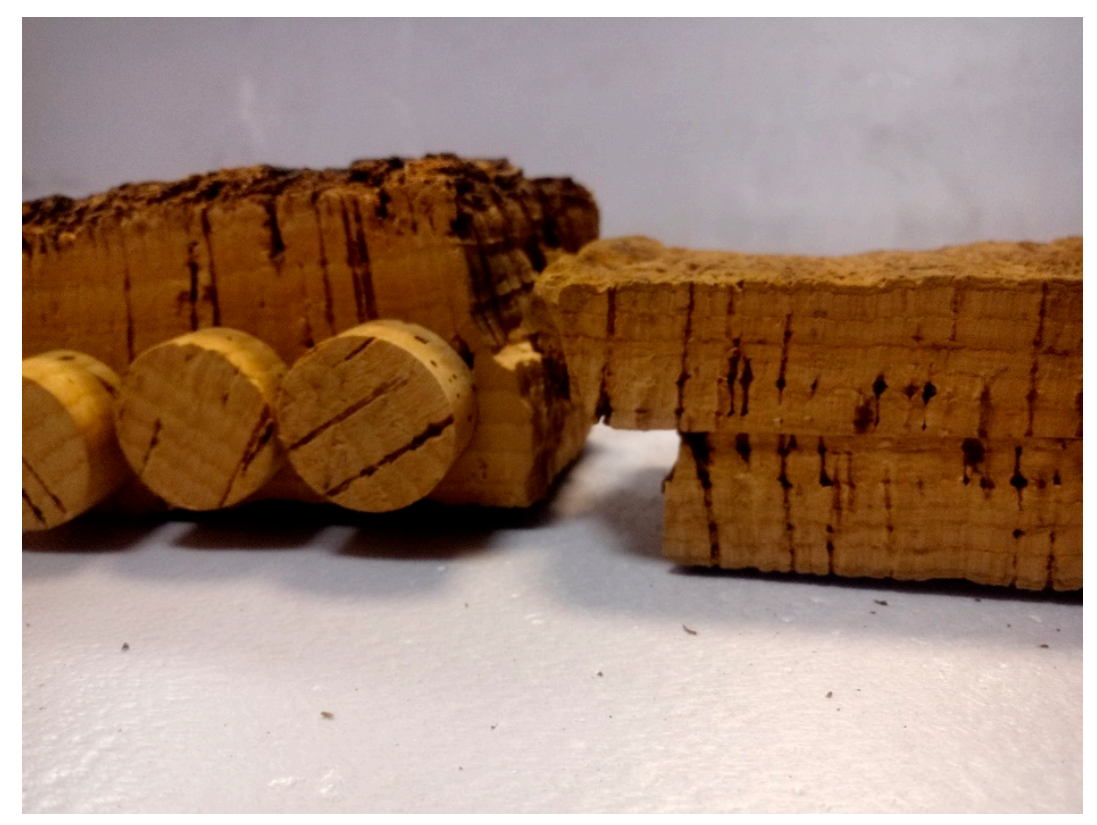

Figure 1. Perforated cork sheet to obtain one-piece stoppers on the left and 2 thin cork sheets glued together to achieve the same useful thickness and manufacture two-piece stoppers on the right.

However, the production process is different and includes additional phases, so, consequently, its environmental impact will also be different, being the object of this study to determine the comparative impact of the manufacture of two-piece stoppers for different diameters and lengths, and production system.

\section{Materials and Methods}

\subsection{Objectives and Scope}

In this article, a gate to gate analysis has been carried out for 2 different geometries 24 and $26 \mathrm{~mm}$ diameter and $44 \mathrm{~mm}$ length and for 2 different production processes, turning process and drilling (perforating) process, considering all the production processes.

For each of these production processes, primary data has been obtained for each of the processes, measuring directly on each of the workstations, the consumption of materials and water, the working times, as well as the waste produced, and their destinations and use.

Real measurements have been taken for each of the processes, thus obtaining primary data on material consumption, working hours, electricity and water consumption, as well as all the other data mentioned in the document.

There are two different objectives throughout this research:

- $\quad$ to identify differences between different processes and geometries.

- $\quad$ to identify the critical activities of the production process.

In this way, this study will allow the detection of the critical stages of the production process and the identification of the evolution of the impact of the activity throughout the production activity.

The production process analysis required the use of Simapro 8.3 software and the CML-IA baseline V3.04/EU25 calculation methodology. 
For the analysis of the production process, the Simapro 8.3 software and the CML-IA baseline V3.04/EU25 calculation methodology have been used. The following impact categories have been selected:

- $\quad$ Abiotic Deplation (AD);

- Global Warming-GWP100 (GW);

- Ozone layer depletion (OLD);

- Human toxicity (HT);

- $\quad$ Fresh water aquatic ecotoxicity (FWAE);

- Marine aquatic ecotoxicity (MAE);

- Terrestrial ecotoxicity (TE);

- Photochemical oxidation (PO);

- Acidification (AC);

- Eutrophication (EU).

\subsection{Functional Unit}

After the analysis carried out, a kg of fully processed and marked 2-piece stoppers has been defined as the functional unit for the present study, including the post-treatment and packaging processes.

\subsection{System Limits}

The production processes have been divided into three main blocks:

- initial operations to be carried out on raw cork sheet;

- machining operations to obtain raw stoppers;

- $\quad$ post-treatment and customization and packaging operations.

The limits of the system have been defined so that they include all the activities and processes necessary for the manufacture of finished stoppers and consequently to allow obtaining the functional unit. This includes all the processes necessary for the transformation of unsorted raw plates into packaged finished stoppers (see Figure 2).

Based on the above, the following activities have been considered within the limits of the system:

- Electricity consumption of all equipment and machines used in the production process.

- Labor and associated emissions.

- Consumption of materials throughout the production process.

- Consumption of other resources throughout the production process.

- Complete packaging of the functional unit.

- Recovery of by-products and cork waste for other applications with economic return.

It is specified that the following activities are specifically excluded from the production process:

- The transport of raw materials, whatever their origin, to the production plant.

- Installation and dismantling of production plant.

- Maintenance of machinery and process facilities.

- Management and treatment of waste produced in the process.

- Storage and transportation of finished product to customer facilities. 


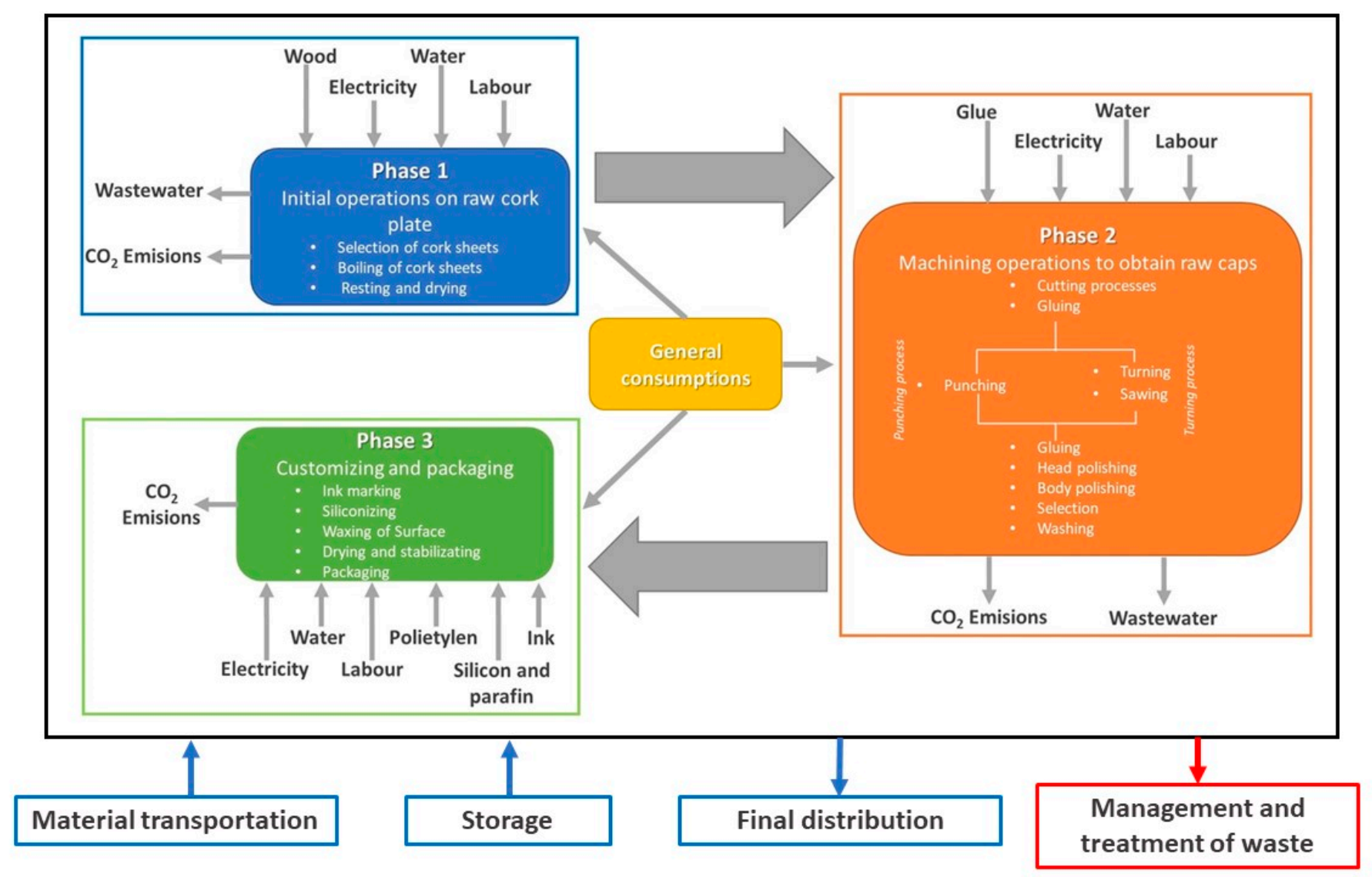

Figure 2. System limits The flowchart displays processes relations and consumption of material, energy, water, and other consumption flows and has been elaborated according to the reality of material, energy, water, and other consumption flows, and these depend on the existing production process $[19,20]$.

\subsection{Assumptions}

The following aspects will be taken into account with respect to the analyzed process:

- Lot characteristics: Raw cork platform. Average load $365 \mathrm{~kg} /$ platform.

- Number of batches studied: for each process analyzed and each dimension and diameter, 10 batches were considered, each consisting of a raw cork platform.

- Cork density: the average density of the worked cork has been $191.37 \mathrm{~kg} / \mathrm{m}^{3}$,

- Volume of caps: $1.99051 \mathrm{E}-05 \mathrm{~m}^{3}$ / stopper for diameter $24 \mathrm{~mm}$ and length $44 \mathrm{~mm}$. and $2.33609 \mathrm{E}-05 \mathrm{~m}^{3}$ /stopper for diameter $26 \mathrm{~mm}$ and length $44 \mathrm{~mm}$.

- Production staff: eight-hour production shift per day and five working days per week.

\subsection{Inventory}

After a detailed analysis of the production process (Figure 3), it has been segmented into three main blocks of processes:

- initial operations to be carried out on raw cork sheet;

- machining operations to obtain raw caps;

- post-treatment and customization and packaging operations.

Next, Tables 1-4 show the summary of the inventory for each of the phases and each of the types of stoppers analyzed. 


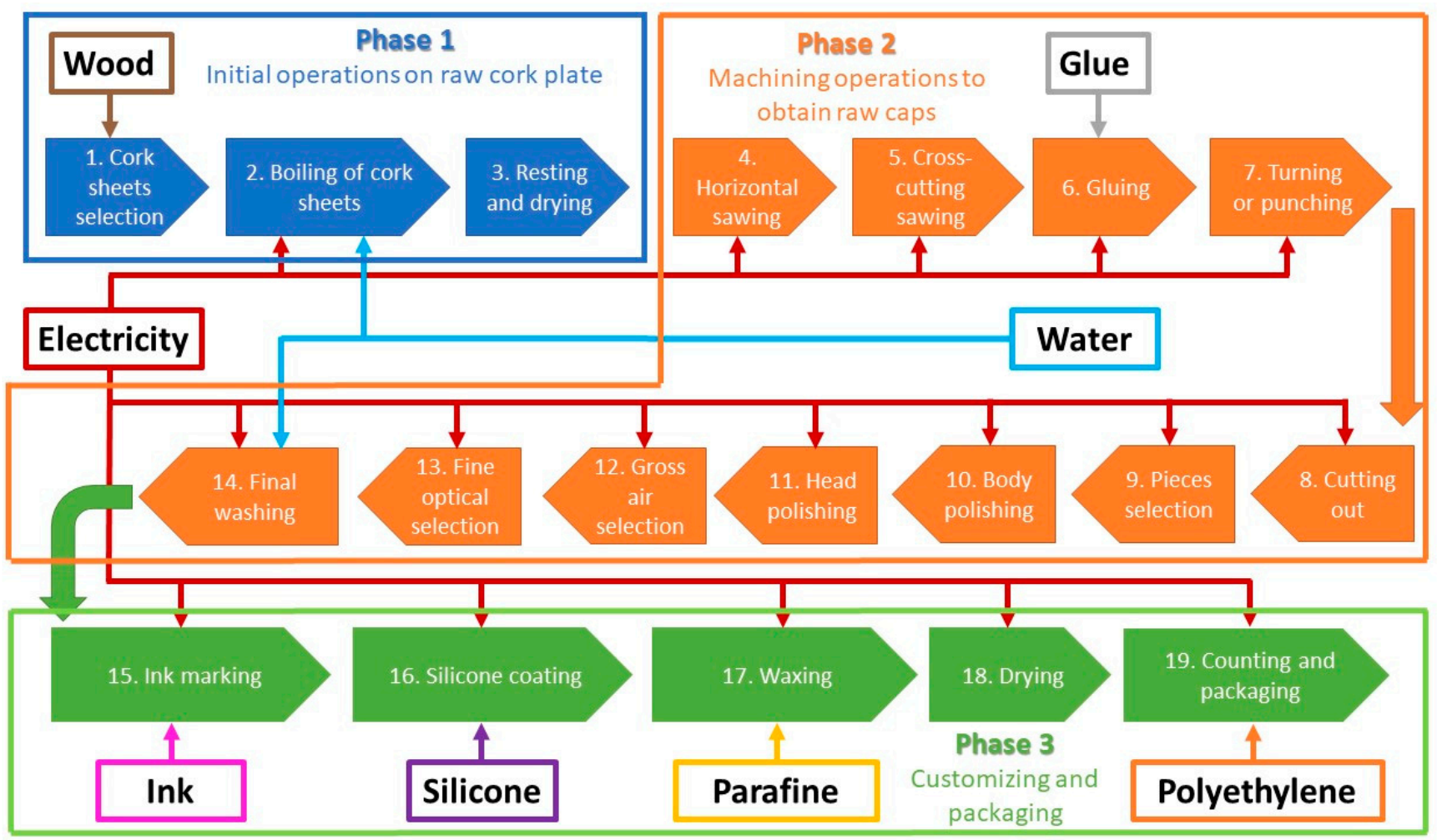

Figure 3. Flowchart.

Table 1. Consumptions for $1000 \mathrm{~kg}$ raw material used to produce 2-piece stoppers with dimensions of $24 \times 44$-Drilled (Perforated) method.

\begin{tabular}{cccc}
\hline & \multicolumn{3}{c}{ 2-Piece Cork 24 $\times$ 44-Perforated } \\
\cline { 2 - 4 } & Phase 1 & Phase 2 & Phase 3 \\
\hline Raw material $(\mathrm{kg})$ & 99.6 & 798.5229723 & -0.642434486 \\
Water $(\mathrm{kg})$ & 2961.150685 & 234.818468 & 0 \\
Energy $(\mathrm{kWh})$ & 394.0489893 & 339.7169957 & 4.757206185 \\
Workforce $(\mathrm{h})$ & 16.47945205 & 54.0239726 & 3.034218613 \\
Glue $(\mathrm{kg})$ & 0 & 6,1983 & 0 \\
Silicone $(\mathrm{kg})$ & 0 & 0 & 0.106978801 \\
Paraffin $(\mathrm{kg})$ & 0 & 0 & 0.535455685 \\
\hline
\end{tabular}

Table 2. Consumption for $1000 \mathrm{~kg}$ raw material used to produce 2-piece stoppers with dimensions $26 \times 44$-Drilled (Perforated) method.

\begin{tabular}{cccc}
\hline & \multicolumn{3}{c}{ 2-Piece Cork 26 $\times$ 44-Perforated } \\
\cline { 2 - 4 } & Phase 1 & Phase 2 & Phase 3 \\
\hline Raw material $(\mathrm{kg})$ & 173.5 & 734.8957104 & -0.492139253 \\
Water $(\mathrm{kg})$ & 2961.150685 & 179.9068018 & 0 \\
Energy $(\mathrm{kWh})$ & 394.0070381 & 297.2638903 & 3.801867111 \\
Workforce $(\mathrm{h})$ & 16.47945205 & 54.0239726 & 2.728139794 \\
Glue $(\mathrm{kg})$ & 0 & 6.1983 & 0 \\
Silicone $(\mathrm{kg})$ & 0 & 0 & 0.081962096 \\
Paraffin $(\mathrm{kg})$ & 0 & 0 & 0.410177157 \\
\hline
\end{tabular}


Table 3. Consumptions for $1000 \mathrm{~kg}$ raw material used to produce 2-piece stoppers with dimensions of $24 \times 44$-Turning method.

\begin{tabular}{cccc}
\hline & \multicolumn{3}{c}{ 2-Piece Cork 24 $\times$ 44-Turned } \\
\cline { 2 - 4 } & Phase 1 & Phase 2 & Phase 3 \\
\hline Raw material (kg) & 103.3 & 799.1195475 & -4.939009633 \\
Water $(\mathrm{kg})$ & 3281.575342 & 224.9152031 & 0 \\
Energy $(\mathrm{kWh})$ & 419.7903808 & 397.2961628 & 4.556575146 \\
Workforce $(\mathrm{h})$ & 15.21917808 & 23.1369863 & 0.228126727 \\
Glue $(\mathrm{kg})$ & 0 & 6.1983 & 0 \\
Silicone $(\mathrm{kg})$ & 0 & 0 & 0.102467063 \\
Paraffin $(\mathrm{kg})$ & 0 & 0 & 0.512873306 \\
\hline
\end{tabular}

Table 4. Consumptions for $1000 \mathrm{~kg}$ raw material used to produce 2-piece stoppers with dimensions of $26 \times 44$-Turning method.

\begin{tabular}{cccc}
\hline & \multicolumn{3}{c}{ 2-Piece Cork 26 $\times$ 44-Turned } \\
\cline { 2 - 4 } & Phase 1 & Phase 2 & Phase 3 \\
\hline Raw material (kg) & 157.9 & 743.6385754 & -4.058037613 \\
Water $(\mathrm{kg})$ & 3281.575342 & 193.3739137 & 0 \\
Energy $(\mathrm{kWh})$ & 419.7607708 & 327.4015667 & 4.256729013 \\
Workforce $(\mathrm{h})$ & 15.21917808 & 23.1369863 & 0.230178959 \\
Glue $(\mathrm{kg})$ & 0 & 6.595 & 0 \\
Silicone $(\mathrm{kg})$ & 0 & 0 & 0.088097455 \\
Paraffin $(\mathrm{kg})$ & 0 & 0 & 0.440881397 \\
\hline
\end{tabular}

The consumption in each phase has been considered for a process input of $1000 \mathrm{~kg}$ of raw cork. The difference between the entrance of raw cork and the consumptions of each phase will correspond to the net use destined to the manufacture of stoppers. The negative values in phase 3 correspond to the reclassification of stoppers and material initially discarded and that later is reprocessed.

\subsubsection{Phase 1: Initial Operations to Be Carried Out on Raw Cork Sheet}

Selection of cork sheets: The raw sheets sent after the cork extraction process must be selected. Those plates that present contamination that could significantly affect the stoppers (green, pitted, earth, rot, yellow stain, etc.) will be eliminated.

Those plates that do not meet the appropriate dimensional criteria for the planned production process are also segregated.

Boiling of cork sheets: Selected raw sheets undergo a hot water boiling process with or without the addition of phenolic additives.

Additive: Sometimes they also receive a steam treatment in order to improve their organoleptic conditions.

Through this process it is possible to sanitize the plate minimizing the subsequent appearance of problems and transfers of odors and flavors while achieving a significant improvement in the mechanical properties of the treated plates by homogenizing the presence of water in the microstructure of the cork and with it its mechanical behavior. By hydrating the iron, an increase of close to $20 \%$ in its volume is achieved (once the excess supply water has been eliminated), substantially increasing its elasticity and softness.

Resting and drying: Once the plates have been cooked, they must be left to rest in order to eliminate excess moisture until reaching approximately $14 \%$ and to stabilize their structure. Although this process has a minimum duration of 15 days, depending on the characteristics of the cork and its specific state, it can take much longer, sometimes reaching several months.

Drying and resting will be carried out under cover but in an open pavilion that allows the air circulation. 
Artificial drying processes are not recommended for treating cork.

\subsubsection{Phase 2: Machining Operations to Obtain Raw Caps}

In this phase, the raw cork sheets are machined to obtain cylindrical stoppers with the required dimensions.

There are two main and different manufacturing processes that have been analyzed throughout this paper:

- Manufacture of perforated stoppers.

- Manufacture of turned stoppers.

In the case of the manufacture of perforated stoppers, the cross-cutting of cork sheets is initially carried out.

After that, the "belly" or inner surface of the cork oak bark will be removed, thus achieving a flat and polished surface, suitable for gluing.

Once this cut has been made, two pieces will be glued, keeping them in a press with pressure and temperature for $24 \mathrm{~h}$.

After finishing the gluing process, the glued strips are subjected to a drilling process and subsequent operations (parting, head polishing, body polishing, selection, etc.) in a similar way to the process carried out in the manufacturing process of a 1-piece stopper.

In the case of turned plugs, the main difference is that, after obtaining strips from the raw plate, two cuts are made to each strip, eliminating the "belly" but also the "back" (outer part of the bark of the cork oak) from cork.

After that, the strips obtained are glued by means of a press with pressure and temperature input and, after $24 \mathrm{~h}$ of stabilization of the glue, the glued strips are extracted from the press and turned into bars.

The bars are cut into plugs using a multiple cutter, after which cylindrical plugs are obtained that are subjected to the rest of the usual processes mentioned above (head polishing, body polishing, selection, etc.).

\subsubsection{Phase 3: Post-Treatment and Customization and Packaging Operations}

In this last block, raw stoppers with the desired size are started and they are subjected to the processes aimed at their organoleptic and aesthetic conditioning as well as their personalization.

Ink marking: Although it is possible to mark the caps with fire or ink, given that the market is increasingly inclined towards ink marking of caps, this process has been considered. Through a continuous rotary marker, the stoppers receive the desired impression on the body. The decoration of the heads is not usual since they will be in contact with the wine.

Siliconizing: In this phase, a liquid silicone film will be applied to the surface of the stopper, improving its tightness and ensuring that the stopper does not deteriorate over the years in contact with the wine.

This process is carried out in a perforated rotary drum with temperature control.

Waxing of surface: The stoppers receive a layer of paraffin in order to ensure that the removal of the stopper is adequate and does not involve excessive effort. This process is carried out in a rotating drum with temperature control.

Drying and stabilizing: once the silicone and waxing processes are finished, the caps are dried and stabilized to avoid possible biological contamination.

Packaging: The finished caps are packed in Polyethylene bags with an oxidizing gas $\left(\mathrm{SO}_{2}\right)$ in order to avoid eventual contamination of the caps until they are used.

\section{Results}

Throughout this work, a LCA has been carried out in order to identify the main environmental impacts associated with the manufacture of two-piece natural cork stoppers from thin sheet cork. 
For this, a gate-to-gate approach has been considered, thus analyzing all the environmental impacts of the production process for stoppers of 24 and $26 \mathrm{~mm}$ diameter and $44 \mathrm{~mm}$ lengths and through drilling and turning technologies for each of the cases.

To carry out the mentioned LCA, SimaPro 8.3 software was used and the CML-IA baseline V3.04/EU25 methodology was applied to calculate the environmental impact.

For the present case, the proposed functional unit has been $1 \mathrm{~kg}$ of fully processed and marked two-piece stoppers, including post-treatment processes and packaging.

The closure manufacturing activities have been divided into three different phases, for which all the impact categories have been determined.

To facilitate the understanding of the results obtained, the global impact of the product is first shown, and subsequently, for each of the proposed plug manufacturing geometries and methodologies, the impacts for each of the phases analyzed are presented.

\subsection{Global Analysis of the Environmental Impact}

The results obtained for each of the impact categories studied and associated with the different geometries and productive methodologies proposed can be seen in Table 5 .

Table 5. Global impact for each geometry and production methodology, by impact categories.

\begin{tabular}{|c|c|c|c|c|c|}
\hline & & $\begin{array}{l}24 \times 442 P \\
\text { Perforated }\end{array}$ & $\begin{array}{l}26 \times 442 P \\
\text { Perforated }\end{array}$ & $\begin{array}{c}24 \times 442 P \\
\text { Turned }\end{array}$ & $\begin{array}{c}26 \times 442 P \\
\text { Turned }\end{array}$ \\
\hline Abiotic depletion & $\mathrm{kg} \mathrm{Sb} \mathrm{eq}$ & 0.002735461 & 0.002731983 & 0.003004334 & 0.00299546 \\
\hline Abiotic depletion (fossil fuels) & MJ & 10690.65995 & 10545.34663 & 11749.76879 & 11510.02109 \\
\hline Global warming (GWP100a) & $\mathrm{kg} \mathrm{CO} 2 \mathrm{eq}$ & 977.7305994 & 963.2864969 & 1076.812504 & 1052.989073 \\
\hline Ozone layer depletion (ODP) & kg CFC-11 eq & 0.000102725 & 0.000100916 & 0.00011299 & 0.000110023 \\
\hline Human toxicity & $\mathrm{kg} 1.4-\mathrm{DB}$ eq & 490.8382666 & 485.8388178 & 540.5864976 & 532.2016483 \\
\hline Fresh water aquatic ecotox. & $\mathrm{kg} 1.4-\mathrm{DB}$ eq & 526.3757405 & 521.1066613 & 580.335491 & 571.7369036 \\
\hline Marine aquatic ecotoxicity & $\mathrm{kg} 1.4-\mathrm{DB}$ eq & 1534271.083 & 1510568.815 & 1693274.685 & 1654770.983 \\
\hline Terrestrial ecotoxicity & $\mathrm{kg} 1.4-\mathrm{DB}$ eq & 8.938554382 & 8.890603038 & 9.803742104 & 9.725492703 \\
\hline Photochemical oxidation & $\mathrm{kg} \mathrm{C}_{2} \mathrm{H}_{4} \mathrm{eq}$ & 0.37385754 & 0.369816267 & 0.404236078 & 0.397468484 \\
\hline Acidification & $\mathrm{kg} \mathrm{SO} 2 \mathrm{eq}$ & 5.719579397 & 5.605312106 & 6.306237612 & 6.119246576 \\
\hline Eutrophication & $\mathrm{kg} \mathrm{PO}_{4}-\mathrm{eq}$ & 2.247685829 & 2.225486034 & 2.476569152 & 2.440110841 \\
\hline
\end{tabular}

A detailed analysis of these data drives to affirm that the manufacturing processes of stoppers by turning generate, for all categories, greater impacts than the traditional turning system.

On the other hand, the geometries of stoppers with a diameter of 26 generate slightly lower impacts than those produced by the manufacture of stoppers with a diameter of $24 \mathrm{~mm}$. However, this effect is much lighter than that associated with the different cap manufacturing methodologies.

\subsection{Analysis of the Impacts Generated in Stage 1 for Each of the Geometries Studied}

Stage 1 is composed of three processes: Cork sheets selection, Boiling of cork sheets, and Resting and Drying.

Table 6 shows the impacts generated by these activities for each of the stopper geometries under study.

Based on the previous data, it is concluded that, since the process so far is similar and the same raw plates are processed, the results obtained at this stage are very similar, yielding very similar results and only differentiated by the suitability of each piece of cork for the process and the geometries chosen.

Subsequently, once the selection of plates based on the geometry as well as their machining begins, those values will change substantially. 
Table 6. Impact of stage 1 broken down by activities for the manufacturing process of 2-piece drilling-perforated stoppers, of $24 \mathrm{~mm}$ in diameter and $44 \mathrm{~mm}$ in length.

\begin{tabular}{|c|c|c|c|c|c|}
\hline & & $\begin{array}{l}\text { Cork Sheets } \\
\text { Selection }\end{array}$ & $\begin{array}{l}\text { Boiling of } \\
\text { Cork Sheets }\end{array}$ & $\begin{array}{l}\text { Resting and } \\
\text { Drying }\end{array}$ & Total \\
\hline Abiotic depletion & $\mathrm{kg} \mathrm{Sb} \mathrm{eq}$ & $7.659 \times 10^{-6}$ & 0.00253652 & $8.9472 \times 10^{-6}$ & 0.00255313 \\
\hline Abiotic depletion (fossil fuels) & MJ & 210.954269 & 8703.63077 & 152.098393 & 9066.68343 \\
\hline Global warming (GWP100a) & $\mathrm{kg} \mathrm{CO} 2 \mathrm{eq}$ & 15.0859119 & 807.818226 & 14.7224994 & 837.626637 \\
\hline Ozone layer depletion (ODP) & $\mathrm{kg} \mathrm{CFC-11} \mathrm{eq}$ & $2.6202 \times 10^{-6}$ & $8.0286 \times 10^{-5}$ & $1.8379 \times 10^{-6}$ & $8.4744 \times 10^{-5}$ \\
\hline Human toxicity & kg 1.4-DB eq & 2.49657001 & 428.496627 & 5.32512908 & 436.318326 \\
\hline Fresh water aquatic ecotox. & kg 1.4-DB eq & 2.63458208 & 470.790845 & 5.22994656 & 478.655374 \\
\hline Marine aquatic ecotoxicity & kg 1.4-DB eq & 2388.83562 & 1300467.37 & 23257.8208 & 1326114.03 \\
\hline Terrestrial ecotoxicity & kg 1.4-DB eq & 0.50703198 & 7.95327691 & 0.04743803 & 8.50774692 \\
\hline Photochemical oxidation & $\mathrm{kg} \mathrm{C}_{2} \mathrm{H}_{4} \mathrm{eq}$ & 0.07623872 & 0.25029771 & 0.00427678 & 0.33081321 \\
\hline Acidification & $\mathrm{kg} \mathrm{SO}_{2} \mathrm{eq}$ & 0.08352229 & 4.48663646 & 0.1138804 & 4.68403916 \\
\hline Eutrophication & $\mathrm{kg} \mathrm{PO}-\mathrm{eq}$ & 0.02217068 & 1.99490029 & 0.0223638 & 2.03943478 \\
\hline
\end{tabular}

\subsection{Analysis of the Impacts Generated in Stage 2 for Each of the Geometries Studied}

Stage 2 in the case of turned stoppers consists of 11 processes during which the raw plate is converted into machined and finished stoppers, although not yet customized or subjected to the finishing processes.

For the present study, the manufacture of these stoppers has been analyzed using drilling technology and turning technology.

Tables 7 and 8 show the impacts generated by this phase, breaking down the impacts of each of the activities for the manufacture of perforated stoppers of $44 \mathrm{~mm}$ in length and 24 and $26 \mathrm{~mm}$ in diameter respectively.

From the comparison of the impacts generated by the caps of $24 \mathrm{~mm}$ and $26 \mathrm{~mm}$ in diameter and $44 \mathrm{~mm}$ in length, a significant reduction in such impacts in all categories can be seen in this phase in those stoppers with a larger diameter.

This is due because, in the case of the perforated process, since the process analyzed works in excess thicknesses in the case of the manufacture of two-piece stoppers when working with thin plates, the raw plate and therefore the raw material necessary to obtain these stoppers is practically the same.

Despite the fact that the number of viable stoppers of $26 \mathrm{~mm}$ will be lower than those obtained for a diameter of $24 \mathrm{~mm}$, the difference in useful volume of the cap and therefore the use of raw material and other inputs will be much greater, thus reducing the impacts generated by each $\mathrm{kg}$ of cork obtained.

In the case of perforated caps, stage 2 consists of 11 processes during which the raw plate is converted into machined and finished stoppers, although not yet customized or subjected to the finishing processes.

Table 7. Impact of stage 1 broken down by activities for the manufacturing process of 2-piece drilling-perforated stoppers, of $26 \mathrm{~mm}$ in diameter and $44 \mathrm{~mm}$ in length.

\begin{tabular}{|c|c|c|c|c|c|}
\hline & & $\begin{array}{l}\text { Cork Sheets } \\
\text { Selection }\end{array}$ & $\begin{array}{c}\text { Boiling of Cork } \\
\text { Sheets }\end{array}$ & $\begin{array}{l}\text { Resting and } \\
\text { Drying }\end{array}$ & Total \\
\hline Abiotic depletion & $\mathrm{kg} \mathrm{Sb} \mathrm{eq}$ & $7.659 \times 10^{-6}$ & 0.00253651 & $8.9472 \times 10^{-6}$ & 0.00255312 \\
\hline Abiotic depletion (fossil fuels) & MJ & 210.954269 & 8703.47757 & 152.098393 & 9066.53024 \\
\hline Global warming (GWP100a) & $\mathrm{kgCO}_{2} \mathrm{eq}$ & 15.0859119 & 807.803397 & 14.7224994 & 837.611808 \\
\hline Ozone layer depletion (ODP) & kg CFC-11 eq & $2.6202 \times 10^{-6}$ & $8.0284 \times 10^{-5}$ & $1.8379 \times 10^{-6}$ & $8.4742 \times 10^{-5}$ \\
\hline Human toxicity & kg 1.4-DB eq & 2.49657001 & 428.491263 & 5.32512908 & 436.312962 \\
\hline Fresh water aquatic ecotox. & $\mathrm{kg} 1.4-\mathrm{DB}$ eq & 2.63458208 & 470.785577 & 5.22994656 & 478.650106 \\
\hline Marine aquatic ecotoxicity & kg 1.4-DB eq & 2388.83562 & 1300443.95 & 23257.8208 & 1326090.6 \\
\hline Terrestrial ecotoxicity & $\mathrm{kg} 1.4-\mathrm{DB}$ eq & 0.50703198 & 7.95322913 & 0.04743803 & 8.50769914 \\
\hline Photochemical oxidation & $\mathrm{kg} \mathrm{C}_{2} \mathrm{H}_{4} \mathrm{eq}$ & 0.07623872 & 0.2502934 & 0.00427678 & 0.3308089 \\
\hline Acidification & $\mathrm{kg} \mathrm{SO}_{2} \mathrm{eq}$ & 0.08352229 & 4.48652176 & 0.1138804 & 4.68392445 \\
\hline Eutrophication & $\mathrm{kg} \mathrm{PO}-\mathrm{eq}$ & 0.02217068 & 1.99487777 & 0.0223638 & 2.03941225 \\
\hline
\end{tabular}


Table 8. Impact of stage 1 broken down by activities for the manufacturing process of 2-piece turned stoppers, of $24 \mathrm{~mm}$ in diameter and $44 \mathrm{~mm}$ in length.

\begin{tabular}{|c|c|c|c|c|c|}
\hline & & $\begin{array}{l}\text { Cork Sheets } \\
\text { Selection }\end{array}$ & $\begin{array}{l}\text { Boiling of } \\
\text { Cork Sheets }\end{array}$ & $\begin{array}{l}\text { Resting and } \\
\text { Drying }\end{array}$ & Total \\
\hline Abiotic depletion & $\mathrm{kg} \mathrm{Sb} \mathrm{eq}$ & $7.659 \times 10^{-6}$ & 0.00279323 & $8.9472 \times 10^{-6}$ & 0.00280984 \\
\hline Abiotic depletion (fossil fuels) & MJ & 210.954269 & 9554.66708 & 152.098393 & 9917.71975 \\
\hline Global warming (GWP100a) & $\mathrm{kg} \mathrm{CO} \mathrm{CO}_{2}$ & 15.0859119 & 886.657521 & 14.7224994 & 916.465933 \\
\hline Ozone layer depletion (ODP) & $\mathrm{kg}$ CFC-11 eq & $2.6202 \times 10^{-6}$ & $8.8029 \times 10^{-5}$ & $1.8379 \times 10^{-6}$ & $9.2488 \times 10^{-5}$ \\
\hline Human toxicity & $\mathrm{kg} 1.4-\mathrm{DB}$ eq & 2.49657001 & 470.925973 & 5.32512908 & 478.747672 \\
\hline Fresh water aquatic ecotox. & kg 1.4-DB eq & 2.63458208 & 517.560579 & 5.22994656 & 525.425108 \\
\hline Marine aquatic ecotoxicity & kg 1.4-DB eq & 2388.83562 & 1427495.77 & 23257.8208 & 1453142.43 \\
\hline Terrestrial ecotoxicity & kg 1.4-DB eq & 0.50703198 & 8.75342614 & 0.04743803 & 9.30789615 \\
\hline Photochemical oxidation & $\mathrm{kg} \mathrm{C}_{2} \mathrm{H}_{4} \mathrm{eq}$ & 0.07623872 & 0.27479557 & 0.00427678 & 0.35531107 \\
\hline Acidification & $\mathrm{kg} \mathrm{SO}_{2} \mathrm{eq}$ & 0.08352229 & 4.91662543 & 0.1138804 & 5.11402812 \\
\hline Eutrophication & $\mathrm{kg} \mathrm{PO}_{4}-\mathrm{eq}$ & 0.02217068 & 2.19302971 & 0.0223638 & 2.23756419 \\
\hline
\end{tabular}

Tables 9 and 10 show the impacts generated by this phase, breaking down the impacts of each of the activities for the manufacture of $44 \mathrm{~mm}$ long and 24 and $26 \mathrm{~mm}$ diameter perforated stoppers, respectively.

Table 9. Impact of stage 1 broken down by activities for the manufacturing process of 2-piece turned stoppers, of $26 \mathrm{~mm}$ in diameter and $44 \mathrm{~mm}$ in length.

\begin{tabular}{|c|c|c|c|c|c|}
\hline & & $\begin{array}{l}\text { Cork Sheets } \\
\text { Selection }\end{array}$ & $\begin{array}{c}\text { Boiling of Cork } \\
\text { Sheets }\end{array}$ & $\begin{array}{l}\text { Resting and } \\
\text { Drying }\end{array}$ & Total \\
\hline Abiotic depletion & $\mathrm{kg} \mathrm{Sb} \mathrm{eq}$ & $7.659 \times 10^{-6}$ & 0.00279322 & $8.9472 \times 10^{-6}$ & 0.00280983 \\
\hline Abiotic depletion (fossil fuels) & MJ & 210.954269 & 9554.55895 & 152.098393 & 9917.61162 \\
\hline Global warming (GWP100a) & $\mathrm{kg} \mathrm{CO} \mathrm{Cq}_{2}$ & 15.0859119 & 886.647055 & 14.7224994 & 916.455466 \\
\hline Ozone layer depletion (ODP) & $\mathrm{kg} \mathrm{CFC-11} \mathrm{eq}$ & $2.6202 \times 10^{-6}$ & $8.8028 \times 10^{-5}$ & $1.8379 \times 10^{-6}$ & $9.2486 \times 10^{-5}$ \\
\hline Human toxicity & kg 1.4-DB eq & 2.49657001 & 470.922187 & 5.32512908 & 478.743887 \\
\hline Fresh water aquatic ecotox. & $\mathrm{kg} 1.4-\mathrm{DB}$ eq & 2.63458208 & 517.556861 & 5.22994656 & 525.42139 \\
\hline Marine aquatic ecotoxicity & $\mathrm{kg} 1.4-\mathrm{DB}$ eq & 2388.83562 & 1427479.24 & 23257.8208 & 1453125.9 \\
\hline Terrestrial ecotoxicity & $\mathrm{kg} 1.4-\mathrm{DB}$ eq & 0.50703198 & 8.75339242 & 0.04743803 & 9.30786243 \\
\hline Photochemical oxidation & $\mathrm{kg} \mathrm{C}_{2} \mathrm{H}_{4} \mathrm{eq}$ & 0.07623872 & 0.27479253 & 0.00427678 & 0.35530803 \\
\hline Acidification & $\mathrm{kg} \mathrm{SO}_{2} \mathrm{eq}$ & 0.08352229 & 4.91654447 & 0.1138804 & 5.11394716 \\
\hline Eutrophication & $\mathrm{kg} \mathrm{PO}_{4}-\mathrm{eq}$ & 0.02217068 & 2.19301381 & 0.0223638 & 2.23754829 \\
\hline
\end{tabular}

As in the previous case and for similar reasons, from the comparison of the impacts generated by the stoppers of $24 \mathrm{~mm}$ and $26 \mathrm{~mm}$ in diameter and $44 \mathrm{~mm}$ in length, a significant reduction in such impacts is observed at this stage in all the categories in those stoppers with a larger diameter.

However, in this case the comparison shows significantly lower differences than those obtained in the case of perforated stoppers.

The difference mainly lies in the fact that in the case of the turning process, the number of caps obtained from $1 \mathrm{~kg}$ of raw material is less than that obtained in the case of perforated stoppers, which dampens the effect associated with the diameter and the use of material depending on it.

\subsection{Analysis of the Impacts Generated in Stage 3 for Each of the Geometries Studied}

Stage 3, the objective of which is the application of final surface treatments, the customization of the stoppers and its packaging, is made up of 5 different processes: ink marking, silicone coating, waxing, drying, and counting and packaging.

Tables 11-14 show the impacts generated by these activities for each of the stopper geometries under study. 
Table 10. Impact of stage 2 broken down by activities for the manufacturing process of two-piece perforated caps of $24 \mathrm{~mm}$ diameter and $44 \mathrm{~mm}$ in length.

\begin{tabular}{|c|c|c|c|c|c|c|c|}
\hline d & & $\begin{array}{l}\text { Horizontal } \\
\text { Sawing }\end{array}$ & $\begin{array}{l}\text { Cross-Cutting } \\
\text { Sawing }\end{array}$ & Gluing & Punching & Cutting Out & Pieces Selection \\
\hline Abiotic depletion & $\mathrm{kg} \mathrm{Sb} \mathrm{eq}$ & $9.79204 \times 10^{-7}$ & $1.41377 \times 10^{-6}$ & 0.000164796 & $1.09573 \times 10^{-6}$ & $2.75878 \times 10^{-7}$ & $1.58861 \times 10^{-6}$ \\
\hline Abiotic depletion (fossil fuels) & MJ & 16.64600967 & 24.03350876 & 1355.837713 & 18.62693063 & 4.689795459 & 27.00562884 \\
\hline Ozone layer depletion (ODP) & $\mathrm{kg}$ CFC-11 eq & $2.01144 \times 10^{-7}$ & $2.90411 \times 10^{-7}$ & $1.49206 \times 10^{-5}$ & $2.2508 \times 10^{-7}$ & $5.66696 \times 10^{-8}$ & $3.26325 \times 10^{-7}$ \\
\hline Human toxicity & $\mathrm{kg} 1.4-\mathrm{DB}$ eq & 0.582794785 & 0.841439111 & 45.93881528 & 0.652148968 & 0.164194806 & 0.945496246 \\
\hline Fresh water aquatic ecotox. & kg 1.4-DB eq & 0.572377785 & 0.826399046 & 39.33888383 & 0.640492317 & 0.161259953 & 0.928596242 \\
\hline Marine aquatic ecotoxicity & kg 1.4-DB eq & 2545.391196 & 3675.035809 & 170901.8665 & 2848.299754 & 717.1306705 & 4129.511593 \\
\hline Photochemical oxidation & $\mathrm{kg} \mathrm{C}_{2} \mathrm{H}_{4} \mathrm{eq}$ & 0.000468061 & 0.000675786 & 0.036215966 & 0.000523761 & 0.00013187 & 0.000759358 \\
\hline Acidification & $\mathrm{kg} \mathrm{SO}_{2} \mathrm{eq}$ & 0.012463342 & 0.017994573 & 0.855607705 & 0.013946514 & 0.003511383 & 0.020219884 \\
\hline \multirow[t]{2}{*}{ Eutrophication } & $\mathrm{kg} \mathrm{PO}_{4}-\mathrm{eq}$ & 0.002447548 & 0.003533769 & 0.172616166 & 0.002738812 & 0.000689565 & 0.003970775 \\
\hline & & Body polishing & Head polishing & Gross air selection & $\begin{array}{l}\text { Fine optical } \\
\text { selection }\end{array}$ & Final washing & Total \\
\hline Abiotic depletion & $\mathrm{kg} \mathrm{Sb} \mathrm{eq}$ & $2.52933 \times 10^{-7}$ & $3.23329 \times 10^{-7}$ & $2.1573 \times 10^{-7}$ & $1.95948 \times 10^{-7}$ & $6.68326 \times 10^{-6}$ & 0.00017782 \\
\hline Abiotic depletion (fossil fuels) & MJ & 4.29973755 & 5.496440505 & 3.667317676 & 3.331027511 & 109.2488265 & 1572.882936 \\
\hline Global warming (GWP100a) & $\mathrm{kgCO}_{2} \mathrm{eq}$ & 0.416196927 & 0.532032856 & 0.354981282 & 0.322429776 & 10.57044332 & 137.5726375 \\
\hline Fresh water aquatic ecotox. & $\mathrm{kg} 1.4-\mathrm{DB}$ eq & 0.147847701 & 0.188996673 & 0.126101763 & 0.11453833 & 3.778297956 & 46.82379159 \\
\hline Marine aquatic ecotoxicity & kg 1.4-DB eq & 657.4857473 & 840.4771804 & 560.7805302 & 509.3573937 & 16701.70698 & 204087.0434 \\
\hline Terrestrial ecotoxicity & $\mathrm{kg} 1.4-\mathrm{DB}$ eq & 0.001341047 & 0.001714287 & 0.001143801 & 0.001038916 & 0.034737868 & 0.419110945 \\
\hline Photochemical oxidation & $\mathrm{kg} \mathrm{C}_{2} \mathrm{H}_{4} \mathrm{eq}$ & 0.000120902 & 0.000154552 & 0.000103119 & $9.36635 \times 10^{-5}$ & 0.003072618 & 0.042319658 \\
\hline Acidification & $\mathrm{kg} \mathrm{SO}_{2} \mathrm{eq}$ & 0.003219336 & 0.004115342 & 0.002745825 & 0.002494035 & 0.081540327 & 1.017858266 \\
\hline Eutrophication & $\mathrm{kg} \mathrm{PO}_{4}-\mathrm{eq}$ & 0.000632212 & 0.00080817 & 0.000539224 & 0.000489778 & 0.016154085 & 0.204620104 \\
\hline
\end{tabular}


Table 11. Impact of stage 2 broken down by activities for the manufacturing process of 2-piece perforated stoppers with a diameter of $26 \mathrm{~mm}$ and $44 \mathrm{~mm}$ in length.

\begin{tabular}{|c|c|c|c|c|c|c|c|}
\hline & & $\begin{array}{l}\text { Horizontal } \\
\text { Sawing }\end{array}$ & $\begin{array}{l}\text { Cross-Cutting } \\
\text { Sawing }\end{array}$ & Gluing & Punching & Cutting Out & Pieces Selection \\
\hline Abiotic depletion & kg Sb eq & $7.98965 \times 10^{-7}$ & $1.17416 \times 10^{-6}$ & 0.000164991 & $9.77652 \times 10^{-7}$ & $2.16819 \times 10^{-7}$ & $1.24853 \times 10^{-6}$ \\
\hline Abiotic depletion (fossil fuels) & MJ & 13.58203958 & 19.96016537 & 1266.643583 & 16.61963209 & 3.685818907 & 21.22434939 \\
\hline Ozone layer depletion (ODP) & kg CFC-11 eq & $1.6412 \times 10^{-7}$ & $2.4119 \times 10^{-7}$ & $1.37492 \times 10^{-7}$ & $2.00825 \times 10^{-7}$ & $4.45379 \times 10^{-8}$ & $2.56466 \times 10^{-7}$ \\
\hline Human toxicity & kg 1.4-DB eq & 0.475521881 & 0.698826957 & 42.71807642 & 0.581871277 & 0.129044503 & 0.743087406 \\
\hline Fresh water aquatic ecotox. & kg 1.4-DB eq & 0.4670223 & 0.686335973 & 35.80586103 & 0.571470784 & 0.126737933 & 0.729805301 \\
\hline Marine aquatic ecotoxicity & kg 1.4-DB eq & 2076.870353 & 3052.16867 & 154931.7793 & 2541.357722 & 563.6096087 & 3245.478836 \\
\hline Photochemical oxidation & $\mathrm{kg} \mathrm{C}_{2} \mathrm{H}_{4} \mathrm{eq}$ & 0.000381907 & 0.00056125 & 0.033585837 & 0.000467319 & 0.00010364 & 0.000596797 \\
\hline Acidification & $\mathrm{kg} \mathrm{SO}_{2} \mathrm{eq}$ & 0.01016926 & 0.014944745 & 0.778614307 & 0.012443592 & 0.002759678 & 0.015891275 \\
\hline \multirow[t]{2}{*}{ Eutrophication } & $\mathrm{kg} \mathrm{PO}_{4}$ - eq & 0.001997036 & 0.002934845 & 0.157790129 & 0.002443669 & 0.000541945 & 0.003120724 \\
\hline & & Body polishing & Head polishing & Gross air selection & $\begin{array}{l}\text { Fine optical } \\
\text { selection }\end{array}$ & Final washing & Total \\
\hline Abiotic depletion & $\mathrm{kg} \mathrm{Sb} \mathrm{eq}$ & $1.98786 \times 10^{-7}$ & $2.58946 \times 10^{-7}$ & $1.72424 \times 10^{-7}$ & $1.56613 \times 10^{-7}$ & $5.1232 \times 10^{-6}$ & 0.000175317 \\
\hline Abiotic depletion (fossil fuels) & MJ & 3.379263359 & 4.401963622 & 2.9311332 & 2.662350576 & 83.74883637 & 1438.839135 \\
\hline Global warming (GWP100a) & $\mathrm{kg} \mathrm{CO} 2 \mathrm{eq}$ & 0.327098808 & 0.426091991 & 0.28372165 & 0.257704596 & 8.103176619 & 123.6597743 \\
\hline Ozone layer depletion (ODP) & kg CFC-11 eq & $4.08336 \times 10^{-8}$ & $5.31915 \times 10^{-8}$ & $3.54186 \times 10^{-8}$ & $3.21708 \times 10^{-8}$ & $1.00957 \times 10^{-6}$ & $1.58275 \times 10^{-5}$ \\
\hline Fresh water aquatic ecotox. & kg 1.4-DB eq & 0.116196933 & 0.151362773 & 0.10078785 & 0.091545683 & 2.896388302 & 41.74351486 \\
\hline Marine aquatic ecotoxicity & kg 1.4-DB eq & 516.7332817 & 673.1174421 & 448.2083569 & 407.1080007 & 12803.32936 & 181259.761 \\
\hline Terrestrial ecotoxicity & kg 1.4-DB eq & 0.00105396 & 0.00137293 & 0.000914192 & 0.000830362 & 0.026629343 & 0.372532835 \\
\hline Photochemical oxidation & $\mathrm{kg} \mathrm{C}_{2} \mathrm{H}_{4} \mathrm{eq}$ & $9.50198 \times 10^{-5}$ & 0.000123777 & $8.24191 \times 10^{-5}$ & $7.48613 \times 10^{-5}$ & 0.002355432 & 0.038428258 \\
\hline Acidification & $\mathrm{kg} \mathrm{SO}_{2} \mathrm{eq}$ & 0.002530151 & 0.003295876 & 0.002194623 & 0.001993378 & 0.062507946 & 0.90734483 \\
\hline Eutrophication & $\mathrm{kg} \mathrm{PO}_{4}$ - eq & 0.00049687 & 0.000647243 & 0.000430979 & 0.000391459 & 0.012383488 & 0.183178388 \\
\hline
\end{tabular}


Table 12. Impact of stage 2 broken down by activities for the manufacturing process of 2-piece turned stoppers of $24 \mathrm{~mm}$ diameter and $44 \mathrm{~mm}$ in length.

\begin{tabular}{|c|c|c|c|c|c|c|c|}
\hline & & $\begin{array}{l}\text { Horizontal } \\
\text { Sawing }\end{array}$ & $\begin{array}{l}\text { Cross-Cutting } \\
\text { Sawing }\end{array}$ & Gluing & Turning & Cutting Out & Pieces Selection \\
\hline Abiotic depletion & $\mathrm{kg} \mathrm{Sb} \mathrm{eq}$ & $9.7518 \times 10^{-7}$ & $2.00757 \times 10^{-6}$ & 0.000176169 & $1.64611 \times 10^{-6}$ & $3.02227 \times 10^{-7}$ & $1.6872 \times 10^{-6}$ \\
\hline Abiotic depletion (fossil fuels) & $\mathrm{MJ}$ & 16.57760648 & 34.12776586 & 1549.171728 & 27.98319182 & 5.137714018 & 28.68165549 \\
\hline Ozone layer depletion (ODP) & kg CFC-11 eq & $2.00317 \times 10^{-7}$ & $4.12386 \times 10^{-7}$ & $1.72567 \times 10^{-5}$ & $3.38137 \times 10^{-7}$ & $6.2082 \times 10^{-8}$ & $3.46577 \times 10^{-7}$ \\
\hline Human toxicity & $\mathrm{kg} 1.4-\mathrm{DB}$ eq & 0.580399915 & 1.194849959 & 52.70764798 & 0.979721782 & 0.179876919 & 1.00417575 \\
\hline Fresh water aquatic ecotox. & $\mathrm{kg} 1.4-\mathrm{DB}$ eq & 0.570025722 & 1.173492952 & 45.98672891 & 0.962210023 & 0.17666176 & 0.986226895 \\
\hline Marine aquatic ecotoxicity & kg 1.4-DB eq & 2534.931459 & 5218.578897 & 200465.1493 & 4278.993676 & 785.623239 & 4385.797847 \\
\hline Photochemical oxidation & $\mathrm{kg} \mathrm{C}_{2} \mathrm{H}_{4} \mathrm{eq}$ & 0.000466137 & 0.000959622 & 0.041652228 & 0.000786845 & 0.000144465 & 0.000806485 \\
\hline Acidification & $\mathrm{kg} \mathrm{SO}_{2} \mathrm{eq}$ & 0.012412126 & 0.025552431 & 1.000362389 & 0.020951813 & 0.003846753 & 0.021474773 \\
\hline \multirow[t]{2}{*}{ Eutrophication } & $\mathrm{kg} \mathrm{PO}_{4}-\mathrm{eq}$ & 0.00243749 & 0.005017979 & 0.20104305 & 0.004114511 & 0.000755424 & 0.00421721 \\
\hline & & Body polishing & Head polishing & Gross air selection & $\begin{array}{l}\text { Fine optical } \\
\text { selection }\end{array}$ & Final washing & Total \\
\hline Abiotic depletion & $\mathrm{kg} \mathrm{Sb} \mathrm{eq}$ & $2.6863 \times 10^{-7}$ & $3.22979 \times 10^{-7}$ & $2.08448 \times 10^{-7}$ & $1.87684 \times 10^{-7}$ & $6.4014 \times 10^{-6}$ & 0.000190176 \\
\hline Abiotic depletion (fossil fuels) & MJ & 4.566588388 & 5.490500551 & 3.543511261 & 3.190544319 & 104.6413522 & 1783.112158 \\
\hline Global warming (GWP100a) & $\mathrm{kgCO} 2 \mathrm{eq}$ & 0.442026992 & 0.531457893 & 0.34299733 & 0.30883158 & 10.12464405 & 157.9221475 \\
\hline Ozone layer depletion (ODP) & kg CFC-11 eq & $5.51808 \times 10^{-8}$ & $6.6345 \times 10^{-8}$ & $4.28183 \times 10^{-8}$ & $3.85532 \times 10^{-8}$ & $1.26142 \times 10^{-6}$ & $2.00806 \times 10^{-5}$ \\
\hline Fresh water aquatic ecotox. & $\mathrm{kg} 1.4-\mathrm{DB}$ eq & 0.157023443 & 0.188792426 & 0.121844644 & 0.109707775 & 3.618951522 & 54.05166607 \\
\hline Marine aquatic ecotoxicity & kg 1.4-DB eq & 698.2907082 & 839.5688843 & 541.8489203 & 487.875688 & 15997.32699 & 236233.9856 \\
\hline Terrestrial ecotoxicity & kg 1.4-DB eq & 0.001424275 & 0.001712435 & 0.001105187 & 0.0009951 & 0.033272829 & 0.484651415 \\
\hline Photochemical oxidation & $\mathrm{kg} \mathrm{C}_{2} \mathrm{H}_{4} \mathrm{eq}$ & 0.000128406 & 0.000154385 & $9.96382 \times 10^{-5}$ & $8.97133 \times 10^{-5}$ & 0.002943033 & 0.048230958 \\
\hline Acidification & $\mathrm{kg} \mathrm{SO}_{2} \mathrm{eq}$ & 0.003419135 & 0.004110894 & 0.002653128 & 0.002388851 & 0.078101434 & 1.175273728 \\
\hline Eutrophication & $\mathrm{kg} \mathrm{PO}_{4}-\mathrm{eq}$ & 0.000671449 & 0.000807296 & 0.000521021 & 0.000469122 & 0.015472801 & 0.235527353 \\
\hline
\end{tabular}


Table 13. Impact of stage 2 broken down by activities for the manufacturing process of 2-piece turned stoppers of $26 \mathrm{~mm}$ diameter and $44 \mathrm{~mm}$ in length.

\begin{tabular}{|c|c|c|c|c|c|c|c|}
\hline & & $\begin{array}{l}\text { Horizontal } \\
\text { Sawing }\end{array}$ & $\begin{array}{l}\text { Cross-Cutting } \\
\text { Sawing }\end{array}$ & Gluing & Turning & Cutting Out & Pieces Selection \\
\hline Abiotic depletion & $\mathrm{kg} \mathrm{Sb} \mathrm{eq}$ & $8.47964 \times 10^{-7}$ & $1.64618 \times 10^{-6}$ & 0.000169818 & $1.34947 \times 10^{-6}$ & $2.63956 \times 10^{-7}$ & $1.48859 \times 10^{-6}$ \\
\hline Abiotic depletion (fossil fuels) & $\mathrm{MJ}$ & 14.41499739 & 27.98431493 & 1348.693492 & 22.94035787 & 4.487133999 & 25.30529903 \\
\hline Ozone layer depletion (ODP) & kg CFC-11 eq & $1.74185 \times 10^{-7}$ & $3.38151 \times 10^{-7}$ & $1.47406 \times 10^{-5}$ & $2.77202 \times 10^{-7}$ & $5.42207 \times 10^{-8}$ & $3.05779 \times 10^{-7}$ \\
\hline Human toxicity & $\mathrm{kg} 1.4-\mathrm{DB}$ eq & 0.504684634 & 0.979761104 & 45.59073245 & 0.803166717 & 0.15709941 & 0.885965862 \\
\hline Fresh water aquatic ecotox. & $\mathrm{kg} 1.4-\mathrm{DB}$ eq & 0.495663792 & 0.962248642 & 38.62717059 & 0.788810741 & 0.154291381 & 0.870129917 \\
\hline Marine aquatic ecotoxicity & kg 1.4-DB eq & 2204.240427 & 4279.165415 & 167478.2768 & 3507.878833 & 686.1410996 & 3869.509068 \\
\hline Photochemical oxidation & $\mathrm{kg} \mathrm{C}_{2} \mathrm{H}_{4} \mathrm{eq}$ & 0.000405328 & 0.000786877 & 0.035892957 & 0.000645048 & 0.000126171 & 0.000711547 \\
\hline Acidification & $\mathrm{kg} \mathrm{SO}_{2} \mathrm{eq}$ & 0.010792919 & 0.020952654 & 0.840047413 & 0.0171761 & 0.003359645 & 0.018946798 \\
\hline \multirow[t]{2}{*}{ Eutrophication } & $\mathrm{kg} \mathrm{PO}_{4}-\mathrm{eq}$ & 0.00211951 & 0.004114676 & 0.169854345 & 0.003373038 & 0.000659766 & 0.003720767 \\
\hline & & Body polishing & Head polishing & Gross air selection & $\begin{array}{l}\text { Fine optical } \\
\text { selection }\end{array}$ & Final washing & Total \\
\hline Abiotic depletion & $\mathrm{kg} \mathrm{Sb} \mathrm{eq}$ & $2.37007 \times 10^{-7}$ & $2.83878 \times 10^{-7}$ & $1.89408 \times 10^{-7}$ & $1.75351 \times 10^{-7}$ & $5.50972 \times 10^{-6}$ & 0.00018181 \\
\hline Abiotic depletion (fossil fuels) & MJ & 4.029017249 & 4.825795701 & 3.219852168 & 2.980878765 & 90.06936077 & 1548.9505 \\
\hline Global warming (GWP100a) & $\mathrm{kgCO}_{2} \mathrm{eq}$ & 0.389992314 & 0.467117194 & 0.311668459 & 0.288536816 & 8.714725399 & 134.31785 \\
\hline Ozone layer depletion (ODP) & kg CFC-11 eq & $4.8685 \times 10^{-8}$ & $5.83129 \times 10^{-8}$ & $3.89074 \times 10^{-8}$ & $3.60197 \times 10^{-8}$ & $1.08576 \times 10^{-6}$ & $1.71579 \times 10^{-5}$ \\
\hline Fresh water aquatic ecotox. & $\mathrm{kg} 1.4-\mathrm{DB}$ eq & 0.138538906 & 0.16593636 & 0.110715534 & 0.102498366 & 3.114968489 & 45.53097272 \\
\hline Marine aquatic ecotoxicity & kg 1.4-DB eq & 616.0890952 & 737.9268748 & 492.357239 & 455.8151002 & 13769.5984 & 198096.9984 \\
\hline Terrestrial ecotoxicity & kg 1.4-DB eq & 0.001256612 & 0.00150512 & 0.001004241 & 0.000929708 & 0.028638747 & 0.406913609 \\
\hline Photochemical oxidation & $\mathrm{kg} \mathrm{C}_{2} \mathrm{H}_{4} \mathrm{eq}$ & 0.00011329 & 0.000135694 & $9.05374 \times 10^{-5}$ & $8.38178 \times 10^{-5}$ & 0.002533196 & 0.041524464 \\
\hline Acidification & $\mathrm{kg} \mathrm{SO}_{2} \mathrm{eq}$ & 0.00301664 & 0.003613211 & 0.002410795 & 0.002231869 & 0.067225541 & 0.989773585 \\
\hline Eutrophication & $\mathrm{kg} \mathrm{PO}_{4}-\mathrm{eq}$ & 0.000592407 & 0.000709561 & 0.000473431 & 0.000438294 & 0.013318027 & 0.199373823 \\
\hline
\end{tabular}


Table 14. Impact of stage 3 broken down by activities for the manufacturing process of perforated stoppers of 2-pieces of $24 \mathrm{~mm}$ in diameter and $44 \mathrm{~mm}$ in length.

\begin{tabular}{|c|c|c|c|c|c|c|c|}
\hline & & Ink Marking & Silicone Coating & Waxing & Drying & $\begin{array}{l}\text { Counting and } \\
\text { Packaging }\end{array}$ & Total \\
\hline Abiotic depletion & $\mathrm{kg} \mathrm{Sb} \mathrm{eq}$ & $3.99196 \times 10^{-7}$ & $1.0427 \times 10^{-6}$ & $2.83187 \times 10^{-6}$ & $9.31642 \times 10^{-8}$ & $1.45415 \times 10^{-7}$ & $4.51234 \times 10^{-6}$ \\
\hline Abiotic depletion (fossil fuels) & $\mathrm{MJ}$ & 3.879728885 & 8.746627243 & 34.41152473 & 1.583747734 & 2.471987204 & 51.09361579 \\
\hline Ozone layer depletion (ODP) & kg CFC-11 eq & $4.15944 \times 10^{-8}$ & $2.53403 \times 10^{-7}$ & $9.6526 \times 10^{-8}$ & $1.91374 \times 10^{-8}$ & $2.98705 \times 10^{-8}$ & $4.40532 \times 10^{-7}$ \\
\hline Human toxicity & kg 1.4-DB eq & 0.124486862 & 0.267216194 & 0.432748548 & 0.05544872 & 0.086546943 & 0.966447267 \\
\hline Fresh water aquatic ecotox. & kg 1.4-DB eq & 0.122416704 & 0.262765725 & 0.371938444 & 0.054457617 & 0.084999984 & 0.896578474 \\
\hline Marine aquatic ecotoxicity & kg 1.4-DB eq & 476.0119299 & 1337.515368 & 1636.314337 & 242.1756096 & 377.9989673 & 4070.016211 \\
\hline Photochemical oxidation & $\mathrm{kg} \mathrm{C}_{2} \mathrm{H}_{4} \mathrm{eq}$ & 0.000110929 & 0.000201278 & 0.000298421 & $4.45326 \times 10^{-5}$ & $6.95086 \times 10^{-5}$ & 0.00072467 \\
\hline Acidification & $\mathrm{kg} \mathrm{SO}_{2} \mathrm{eq}$ & 0.002352501 & 0.004387312 & 0.007905528 & 0.001185797 & 0.001850847 & 0.017681985 \\
\hline Eutrophication & $\mathrm{kg} \mathrm{PO}_{4}-\mathrm{eq}$ & 0.000531177 & 0.001008274 & 0.001495183 & 0.000232866 & 0.000363469 & 0.00363097 \\
\hline
\end{tabular}


From the above data, it can be deduced that the differences between the impacts generated by stoppers of equal dimensions are very small.

However, there are profound differences between stoppers of different diameters regardless of the manufacturing methodology.

This is because these processes mainly consist of the superficial application of treatments or products, so the perimeter/volume relationship is critical.

Likewise, the analysis of the packaging activity is greatly affected by the difference in the net volume of stoppers within the same container bag, since a fixed number of stoppers is included in one of these bags regardless of their geometry, resulting in an impact smaller to greater diameter or length of the plug.

\section{Discussion}

Throughout this paper, a door-to-door LCA of the complete two-piece stopper manufacturing process in 24 and $26 \mathrm{~mm}$ diameters and $44 \mathrm{~mm}$ length is presented, manufactured by both turning or drilling (perforating) techniques.

The LCA has been developed based on real data from a production plant during the manufacturing process of 10 cork platforms weighing $365 \mathrm{~kg} /$ platform for each of the defined geometries.

In this way, precise primary data on the environmental impact of each of the individual activities that define the production process have been obtained.

To help accurately identify the influence of each of the manufacturing stages on the impacts generated for each of the geometries and production methodologies proposed, Tables 15-18 show the influence of each of these phases on each of the proposed study elements.

From the above results it can be deduced that, for all the manufacturing processes, stage 1, mainly due to the boiling processes with a considerable consumption of water and energy derived from the heating for boiling the cork sheets, is the one that generates greater impacts.

Stages 2 and 3, although have an influence on the impacts generated, they are much lower.

It is also important to note that the impacts of phase 1 are very similar between the different proposed production methodologies and identical between different geometries manufactured with a single production methodology.

From these data, it can be deduced that there is an important relationship between the volume of use of the raw cork sheets and the impacts generated by the activity since, as it is not possible to classify the sheets until the end of their stabilization process, independently of the selected geometry there will be a consumption of resources directly associated with the processing of each unit of raw cork.

On the other hand, the difference in impacts in phase 1 associated with the turning or drilling processes lies in the different input geometries used which, ultimately, imply slight changes in the consumption of water and energy for boiling the cork.

Throughout this research, a kg of fully processed and marked two-piece stoppers has been defined as the functional unit for the present study, including the post-treatment and packaging processes.

Although this presentation of the results allows them to be analyzed in a homogeneous way and allows their application from the point of view of all the actors in the value chain of the product, it makes their interpretation difficult for wine producers, since a transformation is necessary for each of the geometries shown.

To this effect, Tables 19-22 show the global impacts for a unit of cork stopper of the chosen geometry. 
Table 15. Impact of stage 3 broken down by activities for the manufacturing process of perforated stoppers of 2-pieces of $26 \mathrm{~mm}$ in diameter and $44 \mathrm{~mm}$ in length.

\begin{tabular}{|c|c|c|c|c|c|c|c|}
\hline & & Ink Marking & Silicone Coating & Waxing & Drying & $\begin{array}{l}\text { Counting and } \\
\text { Packaging }\end{array}$ & Total \\
\hline Abiotic depletion & $\mathrm{kg} \mathrm{Sb}$ eq & $3.66576 \times 10^{-7}$ & $8.06203 \times 10^{-7}$ & $2.18252 \times 10^{-6}$ & $7.44507 \times 10^{-8}$ & $1.16206 \times 10^{-7}$ & $3.54596 \times 10^{-6}$ \\
\hline Abiotic depletion (fossil fuels) & $\mathrm{MJ}$ & 3.32520477 & 6.825955703 & 26.58505866 & 1.265626713 & 1.975449103 & 39.97729495 \\
\hline Ozone layer depletion (ODP) & kg CFC-11 eq & $3.48937 \times 10^{-8}$ & $1.95653 \times 10^{-7}$ & $7.6657 \times 10^{-8}$ & $1.52933 \times 10^{-8}$ & $2.38705 \times 10^{-8}$ & $3.46367 \times 10^{-8}$ \\
\hline Human toxicity & $\mathrm{kg} 1.4-\mathrm{DB}$ eq & 0.105072373 & 0.209094418 & 0.339365866 & 0.044310959 & 0.069162608 & 0.767006223 \\
\hline Fresh water aquatic ecotox. & $\mathrm{kg} 1.4-\mathrm{DB}$ eq & 0.103349234 & 0.20560664 & 0.292642674 & 0.043518935 & 0.06792638 & 0.713043863 \\
\hline Marine aquatic ecotoxicity & kg 1.4-DB eq & 391.2179863 & 1043.809816 & 1287.826663 & 193.5307715 & 302.0718391 & 3218.457075 \\
\hline Photochemical oxidation & $\mathrm{kg} \mathrm{C}_{2} \mathrm{H}_{4} \mathrm{eq}$ & $9.53368 \times 10^{-5}$ & 0.000157716 & 0.000234918 & $3.55875 \times 10^{-5}$ & $5.55467 \times 10^{-5}$ & 0.000579106 \\
\hline Acidification & $\mathrm{kg} \mathrm{SO}_{2} \mathrm{eq}$ & 0.001937313 & 0.00345472 & 0.006224117 & 0.000947611 & 0.001479075 & 0.014042836 \\
\hline Eutrophication & $\mathrm{kg} \mathrm{PO}_{4}-\mathrm{eq}$ & 0.000449642 & 0.000790828 & 0.001178395 & 0.000186092 & 0.00029046 & 0.002895417 \\
\hline
\end{tabular}

Table 16. Impact of stage 3 broken down by activities for the manufacturing process of 2-piece turning stoppers of $24 \mathrm{~mm}$ in diameter and $44 \mathrm{~mm}$ in length.

\begin{tabular}{|c|c|c|c|c|c|c|c|}
\hline & & Ink Marking & Silicone Coating & Waxing & Drying & $\begin{array}{l}\text { Counting and } \\
\text { Packaging }\end{array}$ & Total \\
\hline Abiotic depletion & $\mathrm{kg} \mathrm{Sb} \mathrm{eq}$ & $3.8197 \times 10^{-7}$ & $9.98725 \times 10^{-6}$ & $2.71244 \times 10^{-6}$ & $8.9235 \times 10^{-8}$ & $1.39282 \times 10^{-7}$ & $4.32165 \times 10^{-6}$ \\
\hline Abiotic depletion (fossil fuels) & $\mathrm{MJ}$ & 3.714262026 & 8.377745836 & 32.96024856 & 1.516954549 & 2.367733291 & 48.93694427 \\
\hline Ozone layer depletion (ODP) & kg CFC-11 eq & $3.98266 \times 10^{-8}$ & $2.42716 \times 10^{-7}$ & $9.24551 \times 10^{-8}$ & $1.83303 \times 10^{-8}$ & $2.86107 \times 10^{-8}$ & $4.21939 \times 10^{-7}$ \\
\hline Human toxicity & $\mathrm{kg} 1.4-\mathrm{DB}$ eq & 0.119190935 & 0.255946583 & 0.414497754 & 0.053110218 & 0.082896901 & 0.925642391 \\
\hline Fresh water aquatic ecotox. & $\mathrm{kg} 1.4-\mathrm{DB}$ eq & 0.117208647 & 0.251683809 & 0.356252263 & 0.052160914 & 0.081415184 & 0.858720818 \\
\hline Marine aquatic ecotoxicity & $\mathrm{kg} 1.4-\mathrm{DB}$ eq & 455.8481318 & 1281.106819 & 1567.304201 & 231.9620636 & 362.0571892 & 3898.278405 \\
\hline Photochemical oxidation & $\mathrm{kg} \mathrm{C}_{2} \mathrm{H}_{4} \mathrm{eq}$ & 0.000106196 & 0.00019279 & 0.000285836 & $4.26545 \times 10^{-5}$ & $6.65771 \times 10^{-5}$ & 0.000694053 \\
\hline Acidification & $\mathrm{kg} \mathrm{SO}_{2} \mathrm{eq}$ & 0.002252817 & 0.004202281 & 0.007572119 & 0.001135787 & 0.001772789 & 0.016935794 \\
\hline Eutrophication & $\mathrm{kg} \mathrm{PO}_{4}-\mathrm{eq}$ & 0.000508569 & 0.000965751 & 0.001432125 & 0.000223046 & 0.00034814 & 0.00347763 \\
\hline
\end{tabular}


Table 17. Impact of stage 3 broken down by activities for the manufacturing process of turning stoppers of 2 -pieces of $26 \mathrm{~mm}$ in diameter and $44 \mathrm{~mm}$ in length.

\begin{tabular}{|c|c|c|c|c|c|c|c|}
\hline & & Ink Marking & Silicone Coating & Waxing & Drying & $\begin{array}{l}\text { Counting and } \\
\text { Packaging }\end{array}$ & Total \\
\hline Abiotic depletion & $\mathrm{kg} \mathrm{Sb} \mathrm{eq}$ & $3.71742 \times 10^{-7}$ & $8.74484 \times 10^{-7}$ & $2.36019 \times 10^{-6}$ & $8.33581 \times 10^{-8}$ & $1.30109 \times 10^{-7}$ & $3.81988 \times 10^{-6}$ \\
\hline Abiotic depletion (fossil fuels) & MJ & 3.540389412 & 7.471756116 & 28.81803365 & 1.417048464 & 2.211795222 & 43.45902287 \\
\hline Global warming (GWP100a) & $\mathrm{kg} \mathrm{CO} 2 \mathrm{eq}$ & 0.321234641 & 0.617759411 & 0.925509406 & 0.137164469 & 0.214092689 & 2.215760616 \\
\hline Ozone layer depletion (ODP) & $\mathrm{kg}$ CFC-11 eq & $3.77256 \times 10^{-8}$ & $2.11928 \times 10^{-7}$ & $8.53306 \times 10^{-8}$ & $1.7123 \times 10^{-8}$ & $2.67264 \times 10^{-8}$ & $3.78833 \times 10^{-7}$ \\
\hline Human toxicity & $\mathrm{kg} 1.4-\mathrm{DB}$ eq & 0.113103466 & 0.229467166 & 0.373274436 & 0.049612398 & 0.077437341 & 0.842894806 \\
\hline Fresh water aquatic ecotox. & $\mathrm{kg} 1.4-\mathrm{DB}$ eq & 0.111229987 & 0.225633927 & 0.322901711 & 0.048725615 & 0.076053209 & 0.784544449 \\
\hline Marine aquatic ecotoxicity & $\mathrm{kg} 1.4-\mathrm{DB}$ eq & 429.2607484 & 1142.563523 & 1421.374297 & 216.685125 & 338.2122321 & 3548.095925 \\
\hline Photochemical oxidation & $\mathrm{kg} \mathrm{C}_{2} \mathrm{H}_{4} \mathrm{eq}$ & 0.000101307 & 0.000173314 & 0.000259334 & $3.98453 \times 10^{-5}$ & $6.21924 \times 10^{-5}$ & 0.000635992 \\
\hline Acidification & $\mathrm{kg} \mathrm{SO}_{2} \mathrm{eq}$ & 0.002122634 & 0.003814283 & 0.006871913 & 0.001060985 & 0.001656034 & 0.015525848 \\
\hline Eutrophication & $\mathrm{kg} \mathrm{PO}_{4}-\mathrm{eq}$ & 0.000483003 & 0.000869852 & 0.001302323 & 0.000208356 & 0.000325212 & 0.003188745 \\
\hline
\end{tabular}


Table 18. Impacts generated by each stage of the activity of manufacturing 2-piece stoppers with dimensions of $24 \times 44$ by drilling.

\begin{tabular}{cccccc}
\hline Impact Category & Unit & Stage 1 & Stage 2 & Stage 3 & Total \\
\hline Abiotic depletion & $\mathrm{kg} \mathrm{Sb} \mathrm{eq}$ & 0.0026 & 0.0002 & $5.00 \times 10^{-6}$ & 0.002805 \\
Abiotic depletion (fossil fuels) & $\mathrm{MJ}$ & 9066.7 & 1572.9 & 51.094 & 10690.694 \\
Global warming (GWP100a) & $\mathrm{kg} \mathrm{CO}$ eq & 837.63 & 137.57 & 2.5313 & 977.7313 \\
Ozone layer depletion (ODP) & $\mathrm{kg} \mathrm{CFC-11} \mathrm{eq}$ & $8.00 \times 10^{-6}$ & $2.00 \times 10^{-5}$ & $4.00 \times 10^{-7}$ & 0.0001004 \\
Human toxicity & $\mathrm{kg} \mathrm{1.4-DB} \mathrm{eq}$ & 436.32 & 53.553 & 0.9664 & 490.8394 \\
Fresh water aquatic ecotox. & $\mathrm{kg} \mathrm{1.4-DB} \mathrm{eq}$ & 478.66 & 46.824 & 0.8966 & 526.3806 \\
Marine aquatic ecotoxicity & $\mathrm{kg} \mathrm{1.4-DB} \mathrm{eq}$ & $1.00 \times 10^{6}$ & 204087 & 4070 & 1208157 \\
Terrestrial ecotoxicity & $\mathrm{kg} \mathrm{1.4-DB} \mathrm{eq}$ & 8.5077 & 0.4191 & 0.0117 & 8.9385 \\
Photochemical oxidation & $\mathrm{kg} \mathrm{C}_{2} \mathrm{H}_{4} \mathrm{eq}$ & 0.3308 & 0.0423 & 0.0007 & 0.3738 \\
Acidification & $\mathrm{kg} \mathrm{SO}_{2} \mathrm{eq}$ & 4.684 & 1.0179 & 0.0177 & 5.7196 \\
Eutrophication & $\mathrm{kg} \mathrm{PO}_{4}$ - eq & 2.0394 & 0.2046 & 0.0036 & 2.2476 \\
\hline
\end{tabular}

Table 19. Impacts generated by each stage of the 2-piece stopper manufacturing activity with dimensions of $26 \times 44$ by drilling.

\begin{tabular}{cccccc}
\hline Impact Category & Unit & Stage 1 & Stage 2 & Stage 3 & Total \\
\hline Abiotic depletion & $\mathrm{kg} \mathrm{Sb} \mathrm{eq}$ & 0.0027 & 0.0026 & 0.0002 & 0.0055 \\
Abiotic depletion (fossil fuels) & $\mathrm{MJ}$ & 10545 & 9066.5 & 1438.8 & 21050.3 \\
Global warming (GWP100a) & $\mathrm{kg} \mathrm{CO}$ eq & 963.29 & 837.61 & 123.66 & 1924.56 \\
Ozone layer depletion (ODP) & $\mathrm{kg} \mathrm{CFC-11} \mathrm{eq}$ & 0.0001 & $8.00 \times 10^{-5}$ & $2.00 \times 10^{-5}$ & 0.0002 \\
Human toxicity & $\mathrm{kg} \mathrm{1.4-DB} \mathrm{eq}$ & 485.84 & 436.31 & 48.759 & 970.909 \\
Fresh water aquatic ecotox. & $\mathrm{kg} \mathrm{1.4-DB} \mathrm{eq}$ & 521.11 & 478.65 & 41.744 & 1041.504 \\
Marine aquatic ecotoxicity & $\mathrm{kg} \mathrm{1.4-DB} \mathrm{eq}$ & $2.00 \times 10^{6}$ & $1.00 \times 10^{6}$ & 181260 & 3181260 \\
Terrestrial ecotoxicity & $\mathrm{kg} \mathrm{1.4-DB} \mathrm{eq}$ & 8.8906 & 8.5077 & 0.3725 & 17.7708 \\
Photochemical oxidation & $\mathrm{kg} \mathrm{C}_{2} \mathrm{H}_{4} \mathrm{eq}$ & 0.3698 & 0.3308 & 0.0384 & 0.739 \\
Acidification & $\mathrm{kg} \mathrm{SO}_{2} \mathrm{eq}$ & 5.6053 & 4.6839 & 0.9073 & 11.1965 \\
Eutrophication & $\mathrm{kg} \mathrm{PO}_{4}$ - eq & 2.2255 & 2.0394 & 0.1832 & 4.4481 \\
\hline
\end{tabular}

Table 20. Impacts generated by each stage of the activity of manufacturing 2-piece stopper with dimensions of $24 \times 44$ by turning.

\begin{tabular}{cccccc}
\hline Impact Category & Unit & Stage 1 & Stage 2 & Stage 3 & Total \\
\hline Abiotic depletion & $\mathrm{kg} \mathrm{Sb} \mathrm{eq}$ & 0.003 & 0.0028 & 0.0002 & 0.006 \\
Abiotic depletion (fossil fuels) & $\mathrm{MJ}$ & 11750 & 9917.7 & 1783.1 & 23450.8 \\
Global warming (GWP100a) & $\mathrm{kg} \mathrm{CO}$ eq & 1076.8 & 916.47 & 157.92 & 2151.19 \\
Ozone layer depletion (ODP) & $\mathrm{kg} \mathrm{CFC-11} \mathrm{eq}$ & 0.0001 & $9.00 \times 10^{-5}$ & $2.00 \times 10^{-5}$ & 0.00021 \\
Human toxicity & $\mathrm{kg} \mathrm{1.4-DB} \mathrm{eq}$ & 540.59 & 478.75 & 60.913 & 1080.253 \\
Fresh water aquatic ecotox. & $\mathrm{kg} \mathrm{1.4-DB} \mathrm{eq}$ & 580.34 & 525.43 & 54.052 & 1159.822 \\
Marine aquatic ecotoxicity & $\mathrm{kg} \mathrm{1.4-DB} \mathrm{eq}$ & $2.00 \times 10^{6}$ & $1.00 \times 10^{6}$ & 236234 & 3236234 \\
Terrestrial ecotoxicity & $\mathrm{kg} \mathrm{1.4-DB} \mathrm{eq}$ & 9.8037 & 9.3079 & 0.4847 & 19.5963 \\
Photochemical oxidation & $\mathrm{kg} \mathrm{C}_{2} \mathrm{H}_{4} \mathrm{eq}$ & 0.4042 & 0.3553 & 0.0482 & 0.8077 \\
Acidification & $\mathrm{kg} \mathrm{SO}_{2} \mathrm{eq}$ & 6.3062 & 5.114 & 1.1753 & 12.5955 \\
Eutrophication & $\mathrm{kg} \mathrm{PO}_{4}$ - eq & 2.4766 & 2.2376 & 0.2355 & 4.9497 \\
\hline
\end{tabular}


Table 21. Impacts generated by each stage of the 2-piece stopper manufacturing activity with dimensions of $26 \times 44$ by turning.

\begin{tabular}{cccccc}
\hline Impact Category & Unit & Stage 1 & Stage 2 & Stage 3 & Total \\
\hline Abiotic depletion & $\mathrm{kg} \mathrm{Sb} \mathrm{eq}$ & 0.003 & 0.0028 & 0.0002 & 0.006 \\
Abiotic depletion (fossil fuels) & $\mathrm{MJ}$ & 11510 & 9917.6 & 1549 & 22976.6 \\
Global warming (GWP100a) & $\mathrm{kg} \mathrm{CO}$ eq & 1053 & 916.46 & 134.32 & 2103.78 \\
Ozone layer depletion (ODP) & $\mathrm{kg} \mathrm{CFC-11} \mathrm{eq}$ & 0.0001 & $9.00 \times 10^{-5}$ & $2.00 \times 10^{-5}$ & 0.00021 \\
Human toxicity & $\mathrm{kg} \mathrm{1.4-DB} \mathrm{eq}$ & 532.2 & 478.74 & 52.615 & 1063.555 \\
Fresh water aquatic ecotox. & $\mathrm{kg} \mathrm{1.4-DB} \mathrm{eq}$ & 571.74 & 525.42 & 45.531 & 1142.691 \\
Marine aquatic ecotoxicity & $\mathrm{kg} \mathrm{1.4-DB} \mathrm{eq}$ & $2.00 \times 10^{6}$ & $1.00 \times 10^{6}$ & 198097 & 3198097 \\
Terrestrial ecotoxicity & $\mathrm{kg} \mathrm{1.4-DB} \mathrm{eq}$ & 9.7255 & 9.3079 & 0.4069 & 19.4403 \\
Photochemical oxidation & $\mathrm{kg} \mathrm{C}_{2} \mathrm{H}_{4}$ eq & 0.3975 & 0.3553 & 0.0415 & 0.7943 \\
Acidification & $\mathrm{kg} \mathrm{SO}_{2}$ eq & 6.1192 & 5.1139 & 0.9898 & 12.2229 \\
Eutrophication & $\mathrm{kg} \mathrm{PO}_{4}$ - eq & 2.4401 & 2.2375 & 0.1994 & 4.877 \\
\hline
\end{tabular}

Table 22. Global impact of each geometry and production methodology, by impact category and for one cork stopper unit.

\begin{tabular}{|c|c|c|c|c|c|}
\hline & & $\begin{array}{l}24 \times 442 \mathrm{P} \\
\text { Perforated }\end{array}$ & $\begin{array}{l}26 \times 442 \mathrm{P} \\
\text { Perforated }\end{array}$ & $\begin{array}{c}24 \times 442 \mathrm{P} \\
\text { Turned }\end{array}$ & $\begin{array}{c}26 \times 442 \mathrm{P} \\
\text { Turned }\end{array}$ \\
\hline Abiotic depletion & $\mathrm{kg} \mathrm{Sb} \mathrm{eq}$ & $1.042 \times 10^{-5}$ & $1.22135 \times 10^{-5}$ & $1.14442 \times 10^{-5}$ & $1.33914 \times 10^{-5}$ \\
\hline Abiotic depletion (fossil fuels) & MJ & 40.72334221 & 47.14373321 & 44.75774719 & 51.45638001 \\
\hline Global warming (GWP100a) & $\mathrm{kg} \mathrm{CO} 2 \mathrm{eq}$ & 3.724415328 & 4.306441809 & 4.101842571 & 4.70746365 \\
\hline Ozone layer depletion (ODP) & kg CFC-11 eq & $3.91305 \times 10^{-7}$ & $4.51152 \times 10^{-7}$ & $4.30407 \times 10^{-7}$ & $4.91866 \times 10^{-7}$ \\
\hline Human toxicity & kg 1.4-DB eq & 1.869723178 & 2.1719775 & 2.059226375 & 2.37924588 \\
\hline Fresh water aquatic ecotox. & $\mathrm{kg} 1.4-\mathrm{DB}$ eq & 2.005094121 & 2.32964494 & 2.210640027 & 2.555991092 \\
\hline Marine aquatic ecotoxicity & kg 1.4-DB eq & 5844.414344 & 6753.106912 & 6450.098008 & 7397.773112 \\
\hline Terrestrial ecotoxicity & $\mathrm{kg} 1.4-\mathrm{DB}$ eq & 0.034049143 & 0.039746083 & 0.037344855 & 0.043478517 \\
\hline Photochemical oxidation & $\mathrm{kg} \mathrm{C}_{2} \mathrm{H}_{4} \mathrm{eq}$ & 0.001424115 & 0.00165329 & 0.001539834 & 0.001776912 \\
\hline Acidification & $\mathrm{kg} \mathrm{SO}_{2} \mathrm{eq}$ & 0.021787279 & 0.025058952 & 0.024022004 & 0.027356533 \\
\hline Eutrophication & $\mathrm{kg} \mathrm{PO}_{4}-\mathrm{eq}$ & 0.008561986 & 0.009949196 & 0.009433858 & 0.010908692 \\
\hline
\end{tabular}

\section{Conclusions}

Throughout the present study, a gate to gate LCA of the complete manufacturing process of two-piece stoppers in diameters 24 and $26 \mathrm{~mm}$ and $44 \mathrm{~mm}$ in length has been carried out, manufactured by both turning or drilling methodologies.

Through this work and attending to first objective of the research, it has been determined that stage 1, corresponding to the initial processing procedures of the plate, its boiling and stabilization, is the one that generates the greatest impacts, well above stage 2 , corresponding to the machining processes of the stopper from the plate, or from phase 3 , corresponding to the post-treatment and personalized processes of the stopper and its packaging for delivery to the customer.

The comparative analysis between different production methodologies and stopper geometries and attending to second objective of the research, shows many similarities in phase 1 because the treatment process of the cork sheet is analogous. However, it must be emphasized that the data are not the same because the caliber of the plates necessary for the manufacture of $26 \mathrm{~mm}$ stopper is greater than in the case of $24 \mathrm{~mm}$ stopper; therefore, for the same initial weight, the number of plates is lower and consequently the consumption is also lower.

As a conclusion to the above, a relationship is established between the volume of use of the raw cork sheets and the impacts generated by the activity.

Considering the impacts generated by the machining and post-treatment processes of the stoppers, it can be concluded that although the impact generated for different methodologies and for different diameters is similar for each $\mathrm{kg}$ of net cork produced, the impact of the larger diameter stoppers will in turn also be much greater because the volume of such stoppers is also considerably higher (more precisely $17.36 \%$ higher). 
Author Contributions: Conceptualization, F.J.F.-M., E.M.C. and J.B.-F.; data curation, F.J.F.-M., J.B.-F., J.L.G.-A. and A.S.-T.L.; formal analysis, A.S.-T.L., J.L.G.-A. and E.J.-M.; investigation, F.J.F.-M., E.M.C. and J.B.-F.; methodology, E.J.-M., E.M.C. and J.B.-F.; resources, J.B.-F. and A.S.-T.L.; validation, F.J.F.-M., E.M.C., J.L.G.-A. and E.J.-M.; visualization, A.S.-T.L.; writing一original draft, F.J.F.-M., J.B.-F. and E.J.-M.; writing-review and editing, A.S.-T.L., E.M.C., J.L.G.-A. and E.J.-M. All authors have read and agreed to the published version of the manuscript.

Funding: This research received no external funding.

Data Availability Statement: The data presented in this study are available on request from the corresponding author. The data are not publicly available due to privacy.

Acknowledgments: The authors appreciate the collaboration from institutions, service users, managers and workers, engineers, technicians, and other people that responded our survey, providing information for this paper.

Conflicts of Interest: The authors declare that there is no conflict of interest. Since there are no funders, they had no role in the design of the study, in the collection, analysis, or interpretation of the data, in the writing of the manuscript, or in the decision to publish the results.

\section{References}

1. Gil, L.; Varela, M.C. Technical Guidelines for Genetic Conservation of Cork Oak (Quercus Suber); Bioversity International: Rome, Italy, 2008.

2. Praciak, A. The CABI Encyclopedia of Forest Trees; CABI: Wallingford, UK, 2013.

3. Cardoso, P.; Gaspar, C.; Pereira, L.C.; Silva, I.; Henriques, S.S.; da Silva, R.R.; Sousa, P. Assessing spider species richness and composition in Mediterranean cork oak forests. Acta Oecol. 2008, 33, 114-127. [CrossRef]

4. Vessella, F.; López-Tirado, J.; Simeone, M.C.; Schirone, B.; Hidalgo, P.J. A tree species range in the face of climate change: Cork oak as a study case for the Mediterranean biome. Eur. J. For. Res. 2017, 136, 555-569. [CrossRef]

5. Magri, D.; Fineschi, S.; Bellarosa, R.; Buonamici, A.; Sebastiani, F.; Schirone, B.; Simeone, M.C.; Vendramin, G.G. The distribution of Quercus suber chloroplast haplotypes matches the palaeogeographical history of the western Mediterranean. Mol. Ecol. 2007, 16, 5259-5266. [CrossRef] [PubMed]

6. Moreira, F.; Duarte, I.; Catry, F.; Acácio, V. Cork extraction as a key factor determining post-fire cork oak survival in a mountain region of southern Portugal. For. Ecol. Manag. 2007, 253, 30-37. [CrossRef]

7. Paulo, J.A.; Tomé, M. Does debarking intensity during the first cork extraction affect future cork thickness? Ann. For. Sci. 2017, 74, 1-9. [CrossRef]

8. Gil, L. New cork-based materials and applications. Materials 2015, 8, 625-637. [CrossRef] [PubMed]

9. Silva, J.S.; Catry, F. Forest fires in cork oak (Quercus suber L.) stands in Portugal. Int. J. Environ. Stud. 2006, 63, 235-257. [CrossRef]

10. Sierra-Pérez, J.; Boschmonart-Rives, J.; Gabarrell, X. Production and trade analysis in the Iberian cork sector: Economic characterization of a forest industry. Resour. Conserv. Recycl. 2015, 98, 55-66. [CrossRef]

11. Mendes, A. A Economia do Sector da Cortiça em Portugal: Evolução das Actividades de Produção e de Transformação ao Longo dos Séculos XIX e XX; Universidade Católica Portuguesa: Porto, Portugal, 2002.

12. Chatonnet, P.; Labadie, D.; Boutou, S. Study of chloroanisoles assay and tca assay validation in wine and cork stoppers soaked in dilute alcohol solution using SIDA-HSSPME-GC-MS/EI-SIM. OENO One 2005, 39, 137-147. [CrossRef]

13. Demertzi, M.; Dias, A.C.; Matos, A.; Arroja, L.M. Evaluation of different end-of-life management alternatives for used natural cork stoppers through life cycle assessment. Waste Manag. 2015, 46, 668-680. [CrossRef] [PubMed]

14. Rives, J.; Fernandez-Rodriguez, I.; Rieradevall, J.; Gabarrell, X. Environmental analysis of raw cork extraction in cork oak forests in southern Europe (Catalonia-Spain). J. Environ. Manag. 2012, 110, 236-245. [CrossRef] [PubMed]

15. Rives, J.; Fernandez-Rodriguez, I.; Rieradevall, J.; Gabarrell, X. Integrated environmental analysis of the main cork products in southern Europe (Catalonia-Spain). J. Clean. Prod. 2013, 51, 289-298. [CrossRef]

16. Rives, J.; Fernandez-Rodriguez, I.; Rieradevall, J.; Gabarrell, X. Environmental analysis of the production of natural cork stoppers in southern Europe (Catalonia-Spain). J. Clean. Prod. 2011, 19, 259-271. [CrossRef]

17. Rives, J.; Fernandez-Rodriguez, I.; Gabarrell, X.; Rieradevall, J. Environmental analysis of cork granulate production in CataloniaNorthern Spain. Resour. Conserv. Recycl. 2012, 58, 132-142. [CrossRef]

18. Rives, J.; Fernández-Rodríguez, I.; Rieradevall, J.; Gabarrell, X. Environmental analysis of the production of champagne cork stoppers. J. Clean. Prod. 2012, 25, 1-13. [CrossRef]

19. Flor, F.J.; Leiva, F.J.; García, J.; Martínez, E.; Jiménez, E.; Blanco, J. Environmental impact of oak barrels production in Qualified Designation of Origin of Rioja. J. Clean. Prod. 2017, 167, 208-217. [CrossRef]

20. Flor, F.J.; Leiva, F.J.; García, J.L.; Martínez, E.; Jiménez, E.; Blanco, J. Environmental impact of wine aging process in oak barrels in wineries of La Rioja (Spain). Am. J. Enol. Vitic. 2018, 69. [CrossRef] 